\title{
Notes on powdery mildews (Erysiphales) in Thailand I. Podosphaera sect. Sphaerotheca
}

\author{
Meeboon $\mathrm{J}^{\mathbf{1}^{*}}$, Hidayat $\mathrm{I}^{\mathbf{2}}$ and Takamatsu $\mathrm{S}^{1}$ \\ ${ }^{1}$ Graduate School of Bioresources, Mie University, 1577 Kurima-machiya, Tsu, 514-8507, Japan \\ ${ }^{2}$ Microbiology Division, Research Center for Biology, Indonesia Institute of Sciences (LIPI), Jl. Raya Jakarta-Bogor \\ KM46, Indonesia
}

Meeboon J, Hidayat I, Takamatsu S 2016 - Notes on powdery mildews (Erysiphales) in Thailand I. Podosphaera sect. Sphaerotheca. Plant Pathology \& Quarantine 6(2), 142-174, Doi $10.5943 / \mathrm{ppq} / 6 / 2 / 5$

\begin{abstract}
Podosphaera sect. Sphaerotheca is a group of powdery mildews mainly infecting herbaceous plants. In tropical countries such as Thailand, asexual morph of Podosphaera is more commonly found than sexual morph. Therefore, studies on diversity and molecular phylogenetics of powdery mildews in Thailand are important. In this study, three species, Po. xanthii, Po. aphanis var. aphanis and Po. pannosa, were determined based on morphological and molecular phylogenetic analyses using ITS sequence. Nine plant species are new world host records of powdery mildews, viz. Cyanthillium cinereum and Spilanthes iabadicensis (Asteraceae), Justicia comata (Acanthaceae), Millingtonia hortensis (Bignoniaceae), Pouzolzia zeylanica (Urticaceae), Hydrocleys nymphoides (Alismataceae), Raphistemma pulchellum, Gymnema inodorum (Apocynaceae) and Leucas decemdentata (Lamiaceae). In addition, 22 new records of Podosphaera were found in Thailand. Phylogenetic affinity of Podosphaera species found in Thailand and related species from other regions is also provided.
\end{abstract}

Key words - anamorph - Erysiphaceae - Podosphera - molecular phylogeny - tropics

\section{Introduction}

Podosphaera Kunze [type species: Po. myrtillina (Schub. : Fr.) Kunze] is a genus of powdery mildew (PM) having ascomata with a single ascus and catenescent conidia with distinct fibrosin bodies (Braun \& Takamatsu 2000, Takamatsu et al. 2010). This genus is divided into two sections, sect. Podosphaera and sect. Sphaerotheca. Taxonomic history of the genus was described in the latest manual of the Erysiphales (Braun \& Cook et al. 2012).

Investigation of PM in Southeast Asia in the past 13 years, in particular Thailand, has contributed to the discovery of new taxa and new records mainly belonging to the tribe Erysipheae (To-anun 2003, 2005, Divarangkoon 2011, Meeboon et al. 2013). From the published data regarding biodiversity of PMs in Thailand, few species of Podosphaera and its asexual morph have been reported, and of these reports only worldwide species have been recorded such as Po. xanthii (Castagne) U. Braun \& Shishkoff and Po. pannosa (Wallr. : Fr.) de Bary (Giatgong et al. 1980). This circumstance encouraged the authors to further intensely investigate the actual biodiversity of 
Podosphaera in Thailand. In this paper, we report nine new host records of PM in the world and 22 new records of the PMs (Po. xanthii, Po. aphanis and Podosphaera spp.) in Thailand. Phylogenetic affinity of Podosphaera species [asexual morph: Fibroidium (R.T.A. Cook, A.J. Inman \& C. Billings) R.T.A. Cook \& U. Braun] found in Thailand and related species from other regions is also provided.

\section{Materials \& Methods}

\section{Morphological examination}

Morphological examinations were conducted according to the procedure described by Meeboon \& Takamatsu (2013). To examine the anamorph, hyphae, conidiophores and conidia of fresh collections were stripped off from the leaf surfaces with clear adhesive tape, mounted on a microscope slide with the fungal mycelium uppermost, and examined in water. Herbarium samples were rehydrated before examination by boiling a small piece of infected leaf containing the fungal mycelium downwards in a drop of lactic acid on an objective glass (Shin \& La et al. 1993). After boiling, the rehydrated mycelium was scraped off, mounted in lactic acid and examined using a light microscope. Thirty conidia and conidiophores were measured for each specimen examined. The specimens were deposited at the National Museum of Nature and Science (TNS) and Mie University Mycological Herbarium (MUMH), Japan. List of abbreviation names provided in Table 1.

\section{Molecular phylogeny}

Whole-cell DNA was extracted from mycelia using the Chelex method (Walsh et al. 1991) as described in Hirata \& Takamatsu (1996). The internal transcribed spacer (ITS) region was amplified by polymerase chain reaction (PCR) using the respective primer pairs of PM5/ITS4 for ITS fragment 1 and ITS5/PM6 (Takamatsu \& Kano et al. 2001) for ITS fragment 2. KOD FX NeoDNA polymerase (Toyobo, Japan) was used in the PCR reaction according to the manufacturer's protocol. The amplicons of ITS region were sent to SolGent Co. (Daejeon, South Korea) for sequencing using primer pair of ITS1 and ITS4 (White et al. 1990).

New representative sequences determined in this study were deposited in DNA Data Base of Japan (DDBJ) under the accession numbers of LC143446-LC145052. Sequences generated from the ITS region were aligned with other Erysiphaceae sequences retrieved from DNA databases (DDBJ, EMBL, NCBI) using MUSCLE (Multiple Sequence Comparison by Log Expectation) (Edgar 2004) implemented in MEGA 5 (Tamura et al. 2011). The alignments were deposited in TreeBASE (http://www.treebase.org/) under the accession number of S19157.

Phylogenetic trees were obtained from the data using the maximum parsimony (MP) analysis by using PAUP* 4.0b10 (Swofford et al. 2002) with the heuristic search option using the tree bisection-reconstruction (TBR) algorithm. This search was repeated 100 times with different random starting points, using the stepwise addition option to increase the likelihood of finding the most parsimonious tree. All sites were treated as unordered and unweighted, with gaps treated as missing data. Tree scores, including tree length (TL), consistency index (CI), retention index (RI) and rescaled consistency index (RC), were also calculated. The strength of the internal branches of the resulting trees was tested with bootstrap (BS) analysis (Felsenstein et al. 1985), using 1000 replications with the stepwise addition option set to simple and a maximum tree number of 100 .

\section{Results}

\section{Taxonomy}

Mycelium on stems and leaves, sometimes on fruits, often covering the entire surface of the leaves, amphigenous or epiphyllous, white to greyish sometimes turning into brown, at first 
forming irregular patches, later effuse, thin to dense, evanescent to \pm persistent, with walls somewhat thickened, smooth to rough, 2-9 $\mu \mathrm{m}$ wide; hyphae branched, substraight to wavy, septate, thin-walled, smooth or almost so, hyaline to subhyaline, 3-9 $\mu \mathrm{m}$ wide; hyphal appressoria sometimes poorly developed, indistinct to nipple-shape, solitary, opposite in pairs or single; conidiophores erect, straight to flexuous, arising from the upper surface of hyphal mother cells, mostly towards one end of the cell but sometimes \pm centrally, single or occasionally two on a hyphal

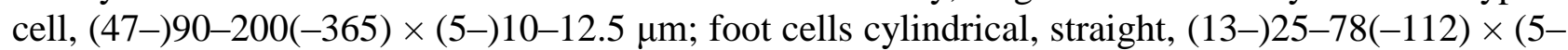
)11-16(-26) $\mu \mathrm{m}$, sometimes slightly constricted at the basal septum or slightly swollen at the base, followed by $1-4(-8)$ shorter cells, forming 3-4(-10) catenescent conidia or in long chains, with a basal septum at the branching point of the mycelium; conidia ellipsoid-ovoid to doliiform, rarely cylindrical, (22.5-)28-38(-45) $\times(12-) 13-40(-43) \mu \mathrm{m}$ with conspicuous fibrosin bodies; germ tubes \pm lateral, simple to forked, short (brevitubus-subtype of the Podosphaera-type).

Sexual morph - not found.

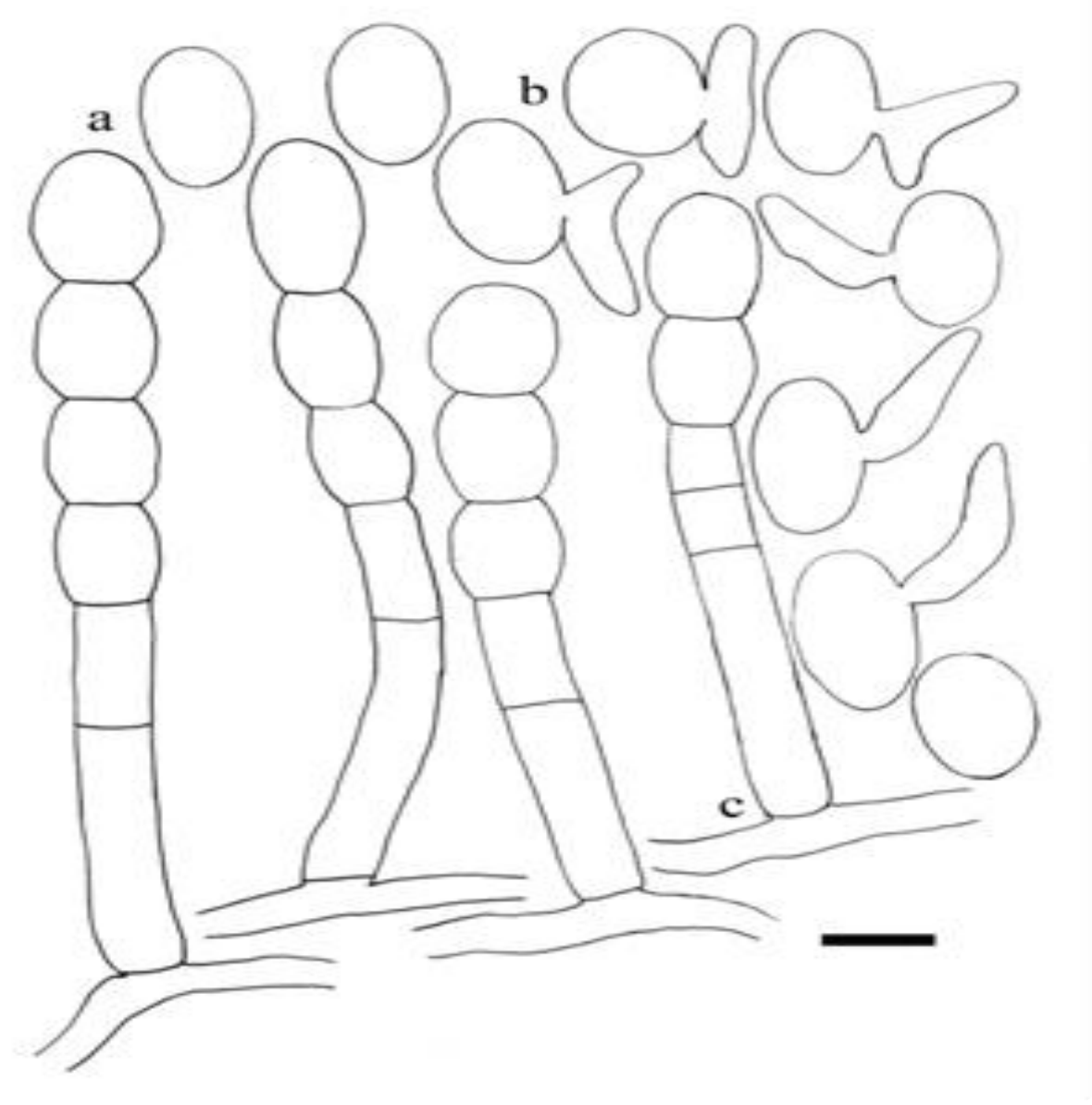

Fig. 1 - Podosphaera xanthii on Justicia comata a conidia. $\mathrm{b}$ germ tubes. $\mathrm{c}$ conidiophores. - Bar $=$ $20 \mu \mathrm{m}$.

Further information - see Braun \& Cook (2012).

Known distribution - almost circumglobal, North and South America, Asia, Australia, Africa, Europe, New Zealand (Braun \& Cook et al. 2012).

Material examined - THAILAND, Chiang Mai Province, Suthep, on Justicia comata (L.) Lam. (Acanthaceae), 8 December 2002, S. Kom-un, MUMH1802; on Cyanthillium cinereum (L.) H. Rob. [syn. Vernonia cinerea (L.) Less.] (Asteraceae), 16 January 2003, S. Kom-un, MUMH1786, MUMH1796; on Galinsoga parviflora Cav. (Asteraceae), 6 December 2015, J. 
Meeboon, MUMH3288; on Impatiens balsamina L. (Balsaminaceae), 6 December 2015, J. Meeboon, MUMH1749, MUMH1780, MUMH3716; on Millingtonia hortensis L. $\mathrm{f}$. (Bignoniaceae), 8 December 2002, S. Kom-un, MUMH1801, MUMH1809; on Heliotropium indicum L. (Boraginaceae), 8 December 2002, S. Kom-un, MUMH1765, MUMH1839; on Cleome rutidosperma DC. (Cleomaceae), 8 December 2002, S. Kom-un, MUMH1753, MUMH1790, MUMH1814; on Vigna radiata (L.) R. Wilczek (Fabaceae), 18 January 2006, J. Meeboon, MUMH3720; Mae Jo, on Macroptilium atropurpureum (Moc. \& Sessé ex DC.) Urb. (Fabaceae), 15 January 2014, J. Meeboon, MUMH1840; Mae Rim, on Carica papaya L. (Caricaceae), 9 January 2016, J. Meeboon, MUMH1853; on Cucumis sativus L. (Cucurbitaceae), 19 January 2016, J. Meeboon, MUMH3727; on Dahlia sp. Cav. (Asteraceae), 19 January 2016, J. Meeboon, MUMH6608; on Gymnema inodorum (Lour.) Decne. (Apocynaceae), 25 January 2003, S. Kom-un, MUMH1830; 12 January 2014, J. Meeboon, MUMH3709; on Momordica charantia L. (Cucurbitaceae), 9 January 2016, J. Meeboon, MUMH3721, MUMH3750; on Euphorbia tithymaloides L. [syn. Pedilanthus tithymaloides (L.) Poit] (Euphorbiaceae), 6 January 2002, S. Kom-un, MUMH1818; on Phaseolus vulgaris L. (Fabaceae), 6 January 2002, S. Kom-un, MUMH1743, MUMH1762; on Senna occidentalis (L.) Link (Fabaceae), 6 January 2002, S. Kom-un, MUMH1852, 12 January 2014, J. Meeboon, MUMH3706; on Solanum melongena L. (Solanaceae), 9 January 2016, J. Meeboon, MUMH1806, MUMH1812, MUMH1827; on Physalis angulata L. (Solanaceae), 9 January 2016, J. Meeboon, MUMH1768, MUMH1804, MUMH1820; Mae Jo, on Macroptilium atropurpureum (DC.) Urb. (Fabaceae), 7 January 2002, S. Kom-un, MUMH1840; on Crotalaria pallida Aiton (Fabaceae), 7 January 2002, S. Kom-un, MUMH1842; on Vigna unguiculata subsp. sesquipedalis (L.) Verdc. (Fabaceae), 7 January 2002, S. Kom-un, MUMH1810, MUMH1834; on Pouzolzia zeylanica (L.) Benn. (Urticaceae), 6 January 2002, S. Kom-un, MUMH1844; on Chamaesyce hirta (L.) Millsp. (Euphorbiaceae), 9 January 2014, J. Meeboon, MUMH3318; Nan Province, on Dahlia pinnata Cav. (Asteraceae), 3 February 2002, S. Kom-un, MUMH1774; on Spilanthes iabadicensis A.H. Moore (Asteraceae), 3 February 2002, S. Kom-un, MUMH1763; Chiang Rai Province, Wiangpapao, on Bidens pilosa L. (Asteraceae), 5 January 2016, J. Meeboon, MUMH1773, MUMH1854; on Cosmos sulphureus Cav. (Asteraceae), 9 January 2016, J. Meeboon, MUMH1846; on Cucurbita pepo L. (Cucurbitaceae), 4 January 2016, J. Meeboon, MUMH1855, MUMH3305; on Euphorbia hirta L. (Euphorbiaceae), 4 January 2016, J. Meeboon, MUMH1751, MUMH1776, MUMH1789, MUMH1829.

Notes - In this study, six plant species are reported as new hosts of Po. xanthii. These are $C y$. cinereum and Spi. iabadicensis (Asteraceae), J. comata (Acanthaceae), Mi. hortensis (Bignoniaceae), M. atropurpureum (Fabaceae) and Pou. zeylanica (Urticaceae). These plants, except Pou. zeylanica, are new hosts for this powdery mildew fungus in the world. In addition, 12 plant species are also reported here as new host records for Po. xanthii in Thailand. These are six species from Fabaceae (Cr. pallida, Ph. vulgaris, Phy. angulata, Sen. occidentalis, V. unguiculata subsp. sesquipedalis, $V$. radiata), two from Asteraceae (D. pinnata, B. pilosa), two from Euphorbiaceae (Eu. hirta, Eu. tithymaloides), Cl. rutidosperma (Cleomaceae), Cu. pepo (Cucurbitaceae) and So. melongena (Solanaceae).

Identification of Po. xanthii complex sensu Braun \& Cook (2012) was based on a combination of morphological and molecular analysis of ITS sequences. The dataset of Hirata et al. (2000) was used to compare the molecular analysis with all PM sequences from Thailand. Notes on the PM specimens belonging to Po. xanthii complex found in Thailand are described below by plant family.

\section{Acanthaceae}

Erysiphe sp., Leveillula sp. and Oidium sp. have been recorded on Justicia spp. (Braun \& Cook et al. 2012). Because this fungus did not produce a sexual morph, PM on J. comata was sequenced and combined with the data matrix of Hirata et al. (2000). The result showed that this fungus has a nucleotide sequence identical to Po. xanthii on Eu. hirta (Euphorbiaceae), Eu. tithymaloides (Euphorbiaceae), C. sativus (Cucurbitaceae), Cu. pepo (Cucurbitaceae), Sen. 
occidentalis (Fabaceae) and Spi. iabadicensis (Asteraceae). In addition, it has a sequence identical to haplotype 27 of Hirata (2000). The haplotypes 16-18 and haplotypes 19-27 belong to the group 3 sensu Hirata (2000). The haplotype of group 3 sensu Hirata (2000) referred to Po. xanthii s. lat. Braun \& Cook (2012) also preferred to maintain powdery mildews on a wide range of plants as Po. xanthii s. lat. Therefore, based on the morphological and molecular characteristics, this fungus is identified as Po. xanthii. This is the first report of PM on J. comata in the world.

Table 1 List of abbreviation names.

\begin{tabular}{ll}
\hline \multicolumn{1}{c}{ Names } & \multicolumn{1}{c}{ Abbreviation } \\
\hline Erysiphe & $E$. \\
Fibroidium & $F$. \\
Oidium & $O$. \\
Golovinomyces & $G$. \\
Neoërysiphe & $N$. \\
Ovulariopsis & $O v$. \\
Podosphaera & $P o$. \\
Pseudoidium & $P$. \\
Sphaerotheca & $S$. \\
Bidens & $B$. \\
Calendula & $C a l$. \\
Carica & $C a$. \\
Cleome & $C l$. \\
Coccinia & $C o$. \\
Cosmos & $C o s$. \\
Crotalaria & $C r$. \\
Cucumis & $C$. \\
Cucurbita & $C u$. \\
Cyanthillium & $C y$. \\
Dahlia & $D$. \\
Euphorbia & Eu. \\
Galinsoga & Ga. \\
\hline &
\end{tabular}

\begin{tabular}{ll}
\hline \multicolumn{1}{c}{ Names } & \multicolumn{1}{c}{ Abbreviation } \\
\hline Gymnema & $G y$. \\
Helianthus & $H e$. \\
Heliotropium & $H$. \\
Hibiscus & $H i$. \\
Impatiens & $I$. \\
Justicia & $J$. \\
Lagenaria & L. \\
Macroptilium & M. \\
Millingtonia & Mi. \\
Momordica & Mo. \\
Phaseolus & $P h$. \\
Physalis & Phy. \\
Pouzolzia & Pou. \\
Prunus & Pr. \\
Senna & Sen. \\
Sesamum & Se. \\
Solanum & So. \\
Spilanthes & Spi. \\
Vigna & V. \\
Viola & Vi. \\
Zinnia & Z. \\
\hline
\end{tabular}

\section{Apocynaceae}

Gymnema inodorum belongs to the family Apocynaceae. This is the first report of PM on $G y$. inodorum in the world. In this study, because we did not find sexual morph of this fungus, only the general morphological characteristics were described in detail. Based on the catenate conidia with fibrosin bodies, the PM on Gy. inodorum is determined as a member of the genus Podosphaera. The phylogenetic tree based on ITS sequence showed that the sequence of PM on Gy. inodorum is identical to the sequence from PM on M. atropurpureum (Fabaceae), Pou. zeylanica (Urticaceae), So. melongena (Solanaceae), Cr. pallida (Fabaceae), V. radiata (Fabaceae) and to haplotype 26 (group 3) of Hirata (2000) (Fig. 23). Based on the morphological and molecular characteristics, this fungus is identified as Po. xanthii. This is the first report of Po. xanthii on Gy. inodorum in the world.

\section{Asteraceae}

Morphological characteristics of PMs infecting Cos. sulphureus, Cy. cinereum, Spi. iabadicensis, D. pinnata, B. pilosa and Ga. parviflora (Asteraceae) in Thailand resemble asexual morph of Podosphaera. PM specimen on Cos. sulhureus is very similar to the asexual morph of Po. 
xanthii, which has been reported on various host plants including Cosmos species worldwide (Braun \& Cook et al. 2012). Therefore, the PM on Cos. sulphureus is named here as Po. xanthii. In addition, there has been no record of PMs from Cy. cinereum worldwide. The molecular analysis showed that PM on $C y$. cinereum has a nucleotide sequence identical to the sequences from Po. xanthii on $H$. indicum (Boragniaceae), D. pinnata (Asteraceae), Phy. angulata (Fabaceae) and haplotype 22 of Hirata (2000). Therefore, this PM is identified as Po. xanthii.

On D. pinnata, two PMs fungi, i.e., Po. fusca and Golovinomyces cichoracearum were reported from Korea (Shin \& Lee 1999, Braun \& Cook et al. 2012). In previous record of PMs from Thailand, Oidium sp. was found on D. rosea (Amano et al. 1986). The morphological characteristics of the present fungus is close to Po. xanthii. Based on molecular analysis, the sequence of this PM is also identical to nucleotide sequence of Podosphaera from $\mathrm{H}$. indicum (Boraginaceae), Cy. cinereum (Asteraceae), Phy. angulata (Fabaceae) and haplotype 22 of Hirata (2000). Therefore, PM on D. pilosa is identified as Po. xanthii.

On Spilanthes, only Spi. acmella has been recorded as a host of Oidium sp. in the world (Amano 1986, Braun \& Cook et al. 2012). The molecular analysis showed that sequence of PM on Spi. iabadicensis is identical to the sequence of Podosphaera on Eu. hirta and Eu. tithymaloides (Euphorbiaceae), C. sativus and Cucur. pepo (Cucurbitaceae), Sen. occidentalis (Fabaceae), J. comatum (Acanthaceae) and haplotype 27 of Hirata (2000). Therefore, this PM is identified as Po. xanthii.

On B. pilosa, three PMs, i.e., G. cichoracearum, Neoërysiphe galeopsidis and Po. fuliginea have been recorded worldwide (Amano 1986, Braun \& Cook et al. 2012). Podosphaera fusca is well known as a PM fungus on Bidens and various host plants in India, Japan, Malaysia, Singapore, Sri Lanka, Taiwan and Korea (Braun \& Cook et al. 2012). The phylogenetic tree showed that sequence of PM from B. pilosa formed a small clade with haplotypes 23 and 24 of Hirata et al. (2000) with 83\% BS support (Fig. 23). Haplotypes 23 and 24 also belong to group 3 which is referred to as Po. xanthii.

On Ga. parviflora, N. cumminsiana (U. Braun) U. Braun is the only PM fungus found on the genus Galinsoga (on Ga. parviflora) (Braun \& Cook et al. 2012). Sphaerotheca fuliginea var. galinsogae Y.S. Paul \& J. Pal was excluded from valid taxa by Braun \& Cook (2012). Molecular phylogenetic analysis based on the rDNA ITS sequence showed that sequence of Ga. parviflora has identical sequence with sequences of Cy. cinereum (Asteraceae), Phy. angulata (Fabaceae), $H$. indicum (Boraginaceae) and haplotype 22 of Hirata (2000) (Fig. 23). Therefore, the current specimen is assigned as Po. xanthii. This is the first report of Podosphaera found on Ga. parviflora in the world. Galinsoga parviflora is reported as new host of PM in Thailand.

\section{Balsaminaceae}

The asexual morph of this fungus is in good agreement with $F$. balsaminae. According to Braun \& Cook (2012), collections of PM on I. balsamina, I. hawkeri, I. textori and New Guinea hybrids, are genetically and biologically distinct from Po. balsaminae that is confined to I. nolitangere. PM on I. balsamina, I. hawkeri, I. textor, and New Guinea hybrids is, therefore, tentatively referred to as Po. xanthii, and asexual morph on these hosts can be assigned to $F$. balsaminae (Braun \& Cook 2012). The current phylogenetic tree based on ITS showed that sequence of PM from I. balsaminae from Thailand (MUMH3716) is nested with sequence of Po. xanthii from various hosts in Thailand (Fig. 23). Therefore, based on the morphological characteristics and notes from Braun \& Cook (2012), PM on I. balsamina from Thailand is identified as Po. xanthii sensu Braun \& Cook (2012). This is the first record of PM on I. balsamina from Thailand.

\section{Bignoniaceae}

Because sexual morph was not found, only asexual morph was described in detail. The phylogenetic tree based on the ITS sequence showed that this fungus groups with sequences of Podosphaera spp., including Po. xanthii (Fig. 23). Therefore, based on the morphological and 
molecular phylogenetic analyses, this fungus is identified as Po. xanthii sensu Braun \& Cook (2012). This is the first record of Podosphaera (Sphaerotheca) on Mi. hortensis in the world.

\section{Boraginaceae}

Fibroidium heliotropii-indici and $P$. heliotropii-strigosi are two PM fungi recorded on $H$. indicum and H. strigosum Willd. worldwide (Amano et al. 1986). Sawada (1933) reported an asexual morph of $O$. heliotropii-indica on $H$. indicum. The general morphology of Podosphaera on H. indicum is in good agreement with the report of Sawada (1933). This fungus was sequenced and combined with data matrix of Hirata et al. (2000). The phylogenetic tree showed that the sequence on H. indicum in Thailand nested with sequence of Po. xanthii from various hosts in Thailand (Fig. 23). The result also showed that the ITS sequence of this fungus is identical to that of Podosphaera on two plants from family Asteraceae (Cy. cinereum and D. pinnata) and Phy. angulata (Fabaceae). Moreover, this fungus has a nucleotide sequence identical to the haplotype 22 of Hirata et al. (2000). Therefore, based on the morphological and molecular characteristics, PM on H. indicum is identified as Po. xanthii sensu Braun \& Cook (2012). This is the first record of PM on H. indicum in Thailand.

\section{Caricaceae}

Eight PM species have been recorded on $C a$. papaya throughout the world (Braun \& Cook et al. 2012), i.e. O. caricae-papayae J.M. Yen (Oidium s. lat.), E. caricae U. Braun \& Bolay [(anamorph: P. caricae (F. Noack) U. Braun \& R.T.A. Cook], L. taurica s. lat., Phyllactinia caricifolia Viégas, Ovulariopsis caricicola U. Braun, Ov. caricae Sawada, Ov. papayae Van der Byl and Po. xanthii (Braun \& Cook et al. 2012).

In the recent monograph of the Erysiphales, Braun \& Cook (2012) noted P. caricae as the asexual morph of $E$. caricae. Another species, $O$. caricae-papayae, is often confused with $P$. caricae. In 1985, the occurrence of a PM on the stem of Ca. papaya, namely $S$. caricae-papayae (syn. Po. caricae-papayae) was reported (Tanda \& Braun et al. 1985). This name is currently listed as a synonym of Po. xanthii (Braun \& Cook et al. 2012). Until now, there is no record of PM occurring on fruit of Ca. papaya. The asexual morph of the PM on fruit and leaf of Ca. papaya from Thailand indicate that this fungus belongs to the genus Podosphaera. Braun \& Cook (2012) noted this species as Po. xanthii. Based on the asexual morph and molecular characteristics, the present fungus is tentatively identified as Po. xanthii (syn. Po. caricae-papayae).

\section{Cleomaceae}

Six PMs, i.e., E. communis, E. radulescui, E. polyphaga, E. cruciiferarum, L. taurica and $S$. fuliginea have been recorded on Cleome spp. worldwide (Amano 1986, Braun \& Cook et al. 2012). However, $\mathrm{Cl}$. rutidosperma has never been recorded as a host of PM. Erysiphe cruciferarum has been recorded on $\mathrm{Cl}$. spinosa by Junell (1967), Shin (1988), and Shin \& La (1989) in Korea. The anamorphic characteristics of the current PM fungus clearly differs from E. cruciferarum due to having conspicuous fibrosin bodies, appressoria single, indistinct and poorly developed, sometimes slightly nipple-shaped, and producing catenescent conidia. The phylogenetic tree showed that the sequence from the current PM specimen has a nucleotide sequence identical to haplotype 21 including Podosphaera sp. on Boehmeria nipononivea (Urticaceae, AB026139). Therefore, based on the morphological and molecular analyses, this fungus is identified as Po. xanthii sensu Braun \& Cook (2012). This is the first record of Podosphaera (Sphaerotheca) on Cl. rutidosperma in Thailand.

\section{Cucurbitaceae}

Podosphaera fusca (Fr.) U. Braun \& Shishkoff [= S. fusca (Fr.) S. Blumer] is a PM species in which the taxonomy is still confusing (Braun \& Cook et al. 2012). Now, Po. fusca is confined to the fungus on Senecioneae of the Asteraceae, not including Cucurbitaceae (Braun \& Cook et al. 2012). We found three PM specimens on Cu. pepo, C. sativus and Mo. charantia in Thailand. The 
morphological characteristics of the three PM specimens are in good agreement with Po. xanthii. Park (2011) reported PM on bitter melon (Mo. charantia) caused by Po. fusca in Korea. This plant is also known as bitter gourd and widely cultivated in tropical and subtropical regions for its edible immature fruit, which is used both as a vegetable and for medicinal purposes. Six PM species have been recorded on Mo. charantia (Farr \& Rossman et al. 2010), viz. G. cichoracearum (from USA, China, South Africa and India), G. orontii (Castagne) Heluta (from United Kingdom and India), $G$. biocellatus (Ehrenb.) Heluta (from Thailand), E. pisi var. pisi (from Pakistan), Po. fuliginea (Schltdl. : Fr.) U. Braun \& S. Takam. (from China, India and Japan) and Po. xanthii. (including Po. fusca) (from Taiwan, India and Korea).

The ITS sequence of PMs on $\mathrm{Cu}$. pepo, $C$. sativus and Mo. charantia are also identical to each other. Molecular analysis of ITS sequence showed that these sequences have a nucleotide sequence identical to Podosphaera on Eu. hirta, Eu. tithymaloides, Sen. occidentalis, J. comata, Spi. iabadicensis and to haplotype 27 of Hirata (2000) (Fig. 23). Therefore, based on the general morphological characteristics and molecular analysis, this fungus is identified as Po.xanthii sensu Braun \& Cook (2012). This is the first record of PMs on Cu. pepo and on Mo. charantia in Thailand.

\section{Euphorbiaceae}

On Eu. hirta, O. euphorbiae-hirtae J.M. Yen (Yen 1966) and O. pedilanthi J.M. Yen (Yen et al. 1967) have been recorded. The later species was also found on Eu. tithymaloides (Yen et al. 1967). Braun \& Cook (2012) noted $O$. pedilanthi as synonym to $O$. euphrobiae-hirtae. The asexual morph of current specimens is similar to O. euphorbiae-hirtae. DNA sequence of this PM fungus is identical to those of Podosphaera on Eu. tithymaloides. The phylogenetic tree showed that PM sequence on Eu. hirta from Thailand formed a small clade with a sequence of PM from Spi. iabadicensis at the terminal of phylogenetic tree with low bootstrap value. The ITS sequence of the current specimen has only one nucleotide difference from Po. euphorbiae-hirtae on Acalypha australis (haplotype 26) (Hirata et al. 2000). The identical nucleotide sequences between Podosphaera on Eu. hirta and Eu. tithymaloides may support the report of Yen (1967) that $O$. pedilanthi on Pedilanthus can cross-infect Euphorbia. The molecular analysis suggests that $O$. euphorbiae-hirtae and $O$. pedilanthi are conspecific. Based on the phylogenetic tree, Po. euphorbiae-hirtae should be a synonym of Po. xanthii (Fig. 23).

\section{Fabaceae}

None of the seven specimens of PMs from the Fabaceae produced a sexual morph at the time of collection. The morphological structures of PMs from Fabaceae (Sen. occidentalis, Ph. vulgaris, M. atropurpureum, Cr. pallida, V. unguiculata subsp. sesquipedalis, V. radiata, Phy. angulata) resemble the asexual morph of the genus Podosphaera. The ITS sequences of these PMs are identical to several haplotypes in group 3 (Haplotype 22, 26 and 27) sensu Hirata (2000). The sequence of PM from Sen. occidentalis is identical to haplotype 27, while sequences of PMs from Ph. vulgaris, M. atropurpureum, Cr. pallida, V. unguiculata subsp. sesquipedalis and V. radiata are were identical to haplotype 26. Sequence from Phy. angulata is identical to haplotype 22. The haplotypes of the group 3 sensu Hirata (2000) referred to Po. xanthii (Hirata 2000, Ito \& Takamatsu et al. 2010).

The phylogenetic tree showed that the sequence of PM from Sen. occidentalis formed a large clade at the terminal of phylogenetic tree with a bootstrap support (BS) of $83 \%$ (Fig. 23). The sequence of this fungus has also a nucleotide sequence identical to Podosphaera sequence from Eu. hirta and Eu. tithymaloides (Euphorbiaceae), Cu. pepo and C. sativus (Cucurbitaceae), Spi. iabadicensis (Asteraceae) and J. comatum (Acanthaceae).

On Phaseolus spp., seven PMs, i.e., Erysiphe communis, E. pisi, E. polygoni, E. diffusa, L. taurica, Po. fuliginea and Po. astragali, were recorded on twenty species of Phaseolus plants worldwide (Amano et al. 1986). Shin (2000) described Po. phaseoli on Fabaceae including Ph. vulgaris in Korea. Only asexual morph was described in that study. Our morphological observation 
showed that the characters of this fungus are in good agreement with Po. phaseoli. However, the phylogenetic tree showed that the ITS sequence of this fungus forms a clade within the group 3 of Hirata (2000) with 65\% BS. PM sequence from Ph. vulgaris is identical to the sequence from PM on $V$. unguiculata var. sesquipedalis. It is also identical to the nucleotide sequence of the fungi on M. atropurpureum (Fabaceae), Pou. zeylanica (Urticaceae), So. melongena (Solanaceae), Cr. pallida (Fabaceae), V. radiata (Fabaceae) and to haplotype 26 (group 3) of Hirata (2000).

The general morphology of PM from $V$. unguiculata var. sesquipedalis is similar to that of Po.(Sphaerotheca) phaseoli on V. sinensis (L.) Savi ex Hausskn. [current name: V. unguiculata (L.) Walp.] described by Shin \& La (1992). Podosphaera phaseoli is currently listed as synonym of Po. xanthii (Braun \& Cook 2012). In addition, Po. xanthii is the only species of PMs from the subtribe Cystothecinae found on plant genus Vigna (Fabaceae) (Braun \& Cook et al. 2012). The PM specimen on $V$. radiata is slightly different from the asexual morph of Po. xanthii as described in Braun \& Cook (2012) by having smaller foot cells (vs 30-100 × 10-13 $\mu \mathrm{m}$ of Po. xanthii). However, phylogenetic analysis based on ITS sequences showed that the current specimen is nested in the clade of Po. xanthii.

Podosphaera fuliginea, E. communis and Oidium sp. have been recorded on three species of Macroptilium worldwide (Amano 1986, Braun \& Cook et al. 2012). Among them, only Oidium sp. has been recorded on $M$. atropurpureum. Molecular analysis showed that the ITS sequence of this PM has a sequence identical to the genus Podosphaera on So. melongena (Solanaceae) and Pou. zeylanica (Urticaceae).

Five PMs, i.e., L. taurica, E. diffusa, E. communis, Po. fuliginea and Oidium sp., have been recorded from nine species of Crotalaria worldwide (Amano 1986, Braun \& Cook et al. 2012). Of them, only Oidium sp. has been recorded on $C r$. pallida. In addition, O. erysiphoides f. crotalariae was described on Crotalaria (Braun et al. 1987), but the status of this species is uncertain.

On Phy. angulata, three PMs, i.e., Po. fuliginea, G. cichoracearum and Oidium sp. have been reported worldwide (Amano 1986, Braun \& Cook et al. 2012). The asexual morph of the PM from Phy. angulata is very close to that of Po. fusca. Molecular analysis showed that this fungus has a nucleotide sequence identical to Podosphaera on $\mathrm{H}$. indicum (Boraginaceae), Cy. cinereum (Asteraceae) and D. pinnata (Asteraceae).

\section{Solanaceae}

Euoidium longipes (Noordel.\& Loer.) U. Braun \& R.T.A. Cook, G. cichoracearum (DC.) Heluta and L. taurica (Lév.) G. Arnaud have been recorded on So. melongena (Braun \& Cook et al. 2012). Another PM, Po. fusca is also well known as PM infecting Solanum spp. worldwide (Braun \& Cook et al. 2012). Characteristic of catenate conidia with fibrosin bodies clearly indicates that the present fungus belongs to the genus Podosphaera. Molecular analysis of the current specimen combined with the data set of Hirata et al. (2000) showed that the ITS sequence of the current specimen is identical to that of Podosphaera on Ph. vulgaris, Cr. pallida, Pou. zeylanica, M. atropurpureum and $V$. sesquipedalis. Moreover, it had a nucleotide sequence identical to the haplotype 26 of Hirata (2000). Therefore, based on the morphological and molecular characteristics, the current PM on So. melongena is identified as Po. xanthii sensu Braun \& Cook (2012). This is the first record of PM on So. melongena from Thailand.

\section{Urticaceae}

The family Urticaceae is commonly infected by numerous PM species worldwide (Amano 1986, Braun \& Cook et al. 2012). However, there is no report on PMs on Pou. zeylanica. Present study is the first report of PM on Pou. zeylanica in the world. The ITS sequence of this fungus was identical to the sequence of Podosphaera on So. melongena (Solanaceae) and on several plants belonging to the family Fabaceae such as Ph. vulgaris, Cr. pallida, M. atropurpureum and $V$. sesquipedalis. In addition, the current PM sequence has a nucleotide sequence identical to the haplotype 26 of Hirata (2000). According to this analysis, Podosphaera on Pou. zeylanica is determined as Po. xanthii sensu Braun \& Cook (2012). 
Mycelium on fruit, stems or leaves, amphigenous, forming irregular patches or effuse, evanescent to persistent; hyphae hyaline, thin-walled, smooth, 3-8 $\mu \mathrm{m}$ wide; hyphal appressoria indistinct to nipple-shaped; conidiophores arising from the upper surface of mother cells, generally towards one end of cell, (145-)172-244(-358) $\mu \mathrm{m}$ long; foot cells cylindrical, $(60-) 89 \times 141(-160)$ $\mu \mathrm{m}, 8-12 \mu \mathrm{m}$ wide near the base, followed by $3-4$ shorter cells, basal septum somewhat elevated above the hyphal mother cells, forming catenescent conidia; conidia ellipsoid-ovoid to doliiformlimoniform, (25-)27-38(-43) $\times(14-) 17-24(-26) \mu \mathrm{m}$, with fibrosin bodies; germ tubes unbranched, 30-70 × 3-4 $\mu \mathrm{m}$ wide with slightly swollen tip (orthotubus-subtype within Podosphaera-type).

Sexual morph - not found.

Further information - see Braun \& Cook (2012)

Known distribution - almost circumglobal, Africa (South Africa, Zimbabwe), North America (Canada, USA, incl. Alaska), Asia (Central Asia, China, Taiwan, India, Iran, Japan, Siberia), Caucasus, all Europe, also in Iceland, South America (Argentina), Australia, New Zealand (Braun $\&$ Cook et al. 2012).

Material examined - THAILAND, Chiang Mai Province, Mae Rim, on Fragaria $\times$ ananassa (Duchesne ex Weston) Duchesne ex Rozier (Rosaceae), 9 January 2016, J. Meeboon, MUMH3739.

Notes - Podosphaera aphanis has been reported on various host plants including Fragaria species worldwide (Braun \& Cook et al. 2012). Two varieties are described by Braun \& Cook (2012), namely, var. aphanis and var. hyalina (U. Braun) U. Braun \& S. Takamatsu. Based on the conidial characteristics, the current PM is close to var. aphanis. According to Braun \& Cook (2012), Po. aphanis var. hyalina has narrow, hyaline and mostly very short appendages. We found this PM in Thailand, but unfortunately the sexual morph was absent from the specimen. The asexual morph clearly resembles the genus Podosphaera. The nucleotide sequence of this PM is identical to that of Po. aphanis on Fragaria grandiflora collected in Japan (AB026136) (Fig. 23). Therefore, based on the morphological and molecular characteristics, PM on Fragaria $\times$ ananassa was identified as Po. aphanis. This is the first report of Po. aphanis var. aphanis on Fragaria $\times$ ananassa from Thailand.

\section{Podosphaera pannosa (Wallr : Fr.) de Bary}

Fig. 3

Mycelium amphigenous and on stems and inflorescences, in irregular patches or effuse, thin to dense, evanescent to \pm persistent; hyphae thin-walled, smooth or almost so, 4-6 $\mu \mathrm{m}$ wide; hyphal appressoria indistinct to slightly nipple-shaped, solitary; conidiophores arising from the upper surface of hyphal mother cells, mostly towards one end of the cell but sometimes \pm centrally, erect; foot cells cylindrical, $(40-) 57-68(-75) \times 10-13 \mu \mathrm{m}$, sometimes slightly constricted at the basal septum or slightly swollen at the very base, followed by $1-2$ shorter cells, forming catenescent conidia; conidia ellipsoid-ovoid to doliiform, (18-)25-30(-40) $\times(16-) 18-20(-22) \mu \mathrm{m}$; germ tubes \pm lateral, simple to forked, short (brevitubus-subtype of the Podosphaera-type).

Sexual morph - not found.

Further information - see Braun \& Cook (2012).

Material examined - THAILAND, Chiang Mai Province, Suthep, on Rosa hybrida L. (Rosaceae), 18 January 2006, J. Meeboon, MUMH3719.

Notes - Podosphaera pannosa is commonly found on Rosa spp. and Prunus s. lat. (Rosaceae) worldwide (Braun \& Cook et al. 2012). Morphological characteristics of this specimen clearly resembled the asexual morph of Podosphaera. Phylogenetic tree generated from ITS sequences showed that sequence of PM on Rosa hybrida from Thailand nested in the same clade with sequence of Po. pannosa on Rosa sp. (AB022348) (Fig. 23). Therefore, the current specimen is determined as Po. pannosa. 


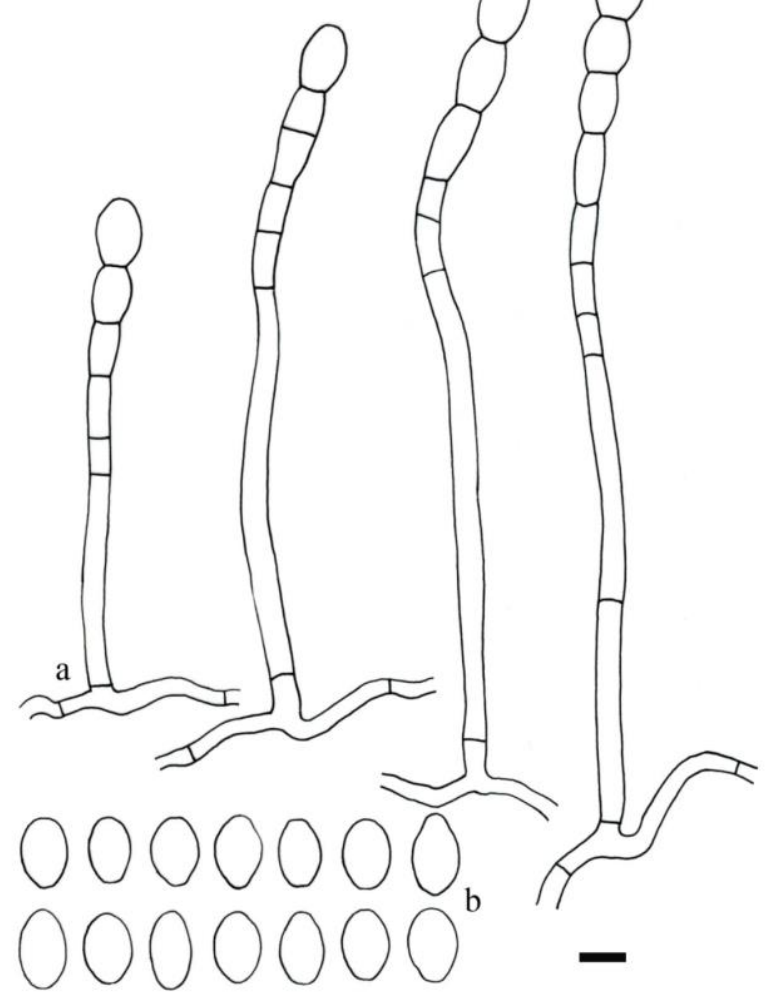

Fig. 2 - Podosphaera aphanis var. aphanis on Fragaria $\times$ ananassa. a conidiophores. b conidia. Bar $=20 \mu \mathrm{m}$.

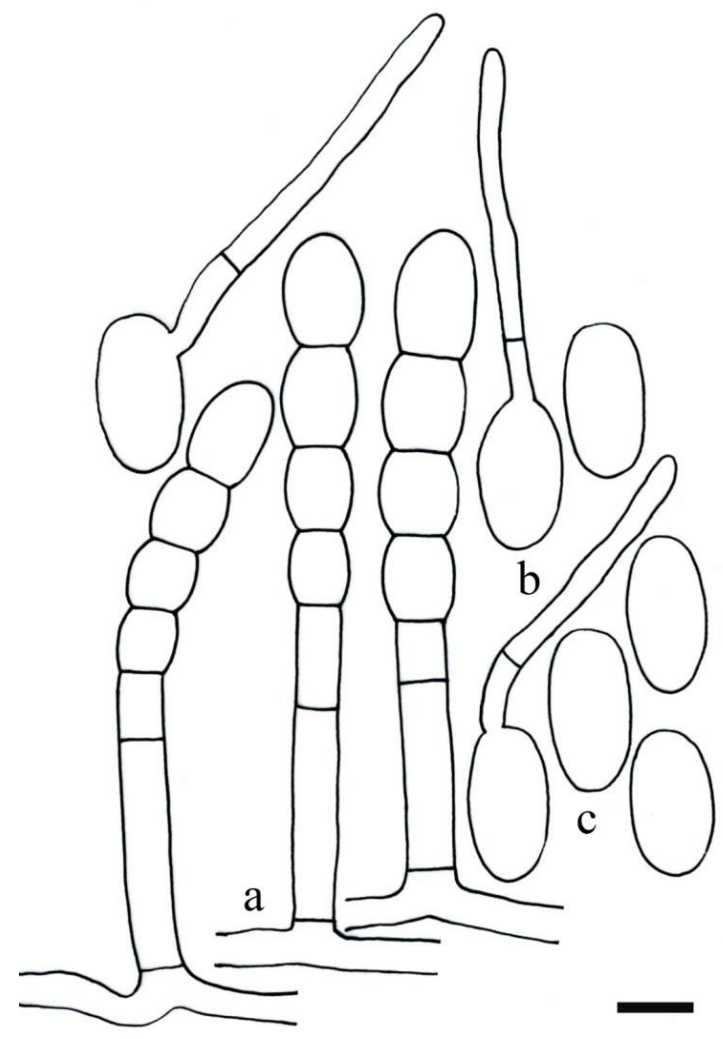

Fig. 3 - Podosphaera pannosa on Rosa hybrida L. a conidiophores. b germ tubes. c conidia. - Bar $=20 \mu \mathrm{m}$. 
4. Podosphaera sp. on Hydrocleys nymphoides

Fig. 4

Mycelium amphigenous, thin, forming irregular patches or effuse, evanescent or \pm persistent, white or greyish white; hyphae 6.5-7.5 $\mu \mathrm{m}$ wide, hyaline, septate, thin-walled, smooth or almost so; hyphal appressoria solitary, slightly to distinctly nipple-shaped, 3-6 $\mu \mathrm{m}$ diam.; conidiophores arising from superficial hyphae, on the upper surface of mother cells, erect, straight, (78-)105143(-170) $\mu \mathrm{m}$ long; foot cells cylindrical, (30-)35-55(-63) $\times 11-12.5 \mu \mathrm{m}$, followed by $1-3$ shorter cells, forming catenescent conidia; conidia ellipsoid-ovoid, doliiform, (30-)32.5-35(-37.5) $\times(15-$ )16-17.5(-20) $\mu \mathrm{m}$.

Material examined - THAILAND, Chiang Mai Province, Suthep, on Hydrocleys nymphoides (Humb. \& Bonpl. ex Willd.) Buchenau (Alismataceae), 20 January 2006, J. Meeboon, MUMH3738.

Notes - Asexual morph indicated that the present fungus belongs to the genus Podosphaera. This is the first report of PM found on Hyd. nymphoides in the world. Molecular analysis is necessary to resolve the identity of this fungus.

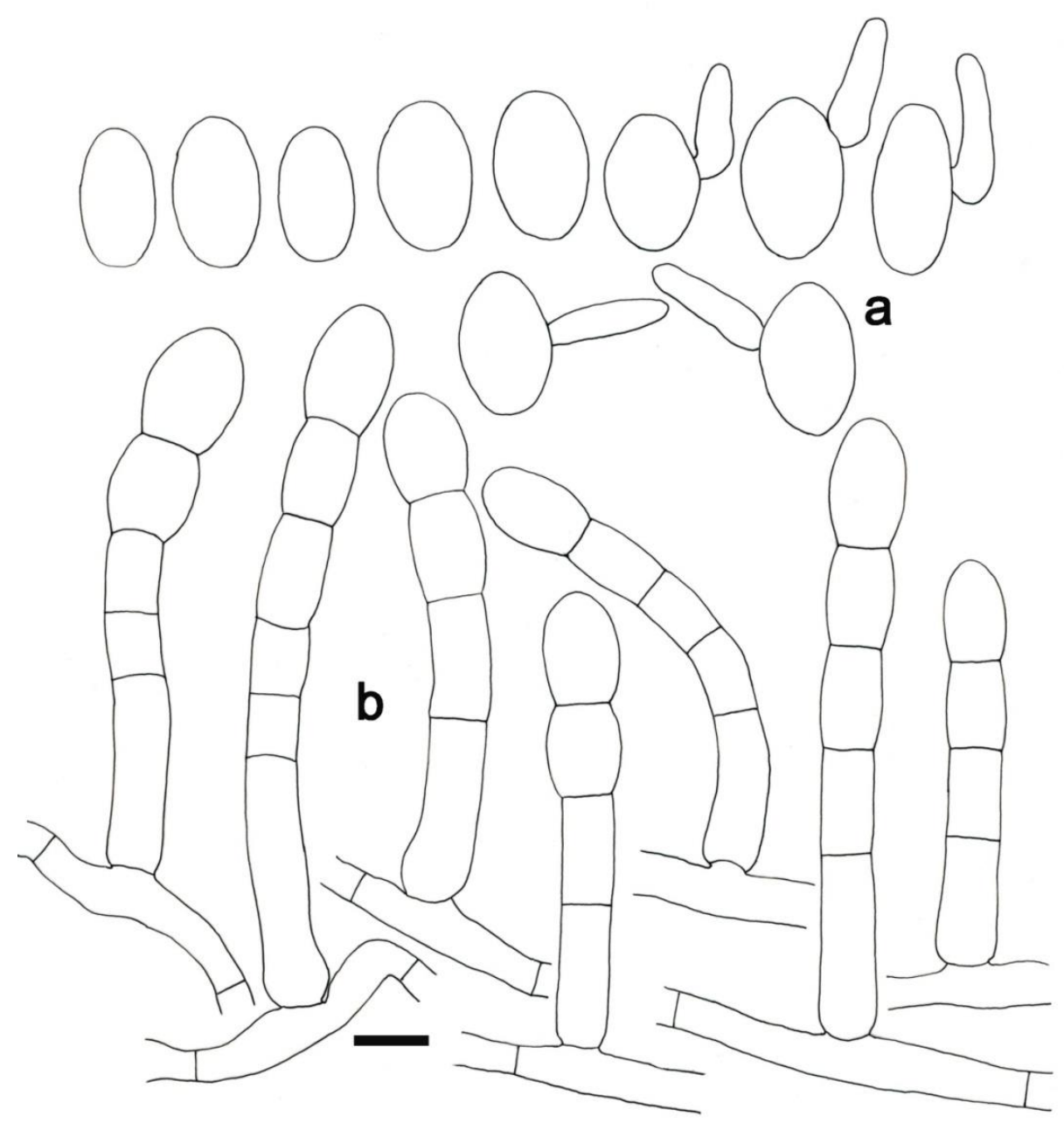

Fig. 4 - Line drawing of Podosphaera sp. on Hydrocleys nymphoides. a conidia. b conidiophores. Bar $=20 \mu \mathrm{m}$.

\section{Podosphaera sp. on Raphistemma pulchellum}

Fig. 5

Mycelium amphigenous, mainly epiphyllous, white, later turning brown, at first forming distinct patches, later effuse; hyphae branched, septate, subhyaline, 4-6 $\mu \mathrm{m}$ wide; hyphal appressoria nipple-shape, opposite in pairs or single; conidiophores erect, single on a hyphal cell 
arising from the side of mother cell; foot cells straight, forming catenescent conidia, with basal septum at the branching point of mycelium; conidia ovoid, 30-35 $\times 15-18 \mu \mathrm{m}$, with conspicuous fibrosin bodies.

Material examined - THAILAND, Nan Province, on Raphistemma pulchellum (Roxb.) Wall. (Apocynaceae), 3 February 2002, S. Kom-un, MUMH1759.

Notes - This study is the first report of PM on Rap. pulchellum in the world. Because we did not find the sexual morph, only the general morphological characteristics of asexual morph are described. Based on the catenate conidia with fibrosin bodies, the PM on Rap. pulchellum belongs to the genus Podosphaera. Comprehensive morphological and molecular studies are necessary to resolve the taxonomic position of this fungus. Unfortunately, we could not obtain complete morphological characteristics and also ITS sequence of this PM for molecular analysis to investigate the taxonomic position of this fungus.

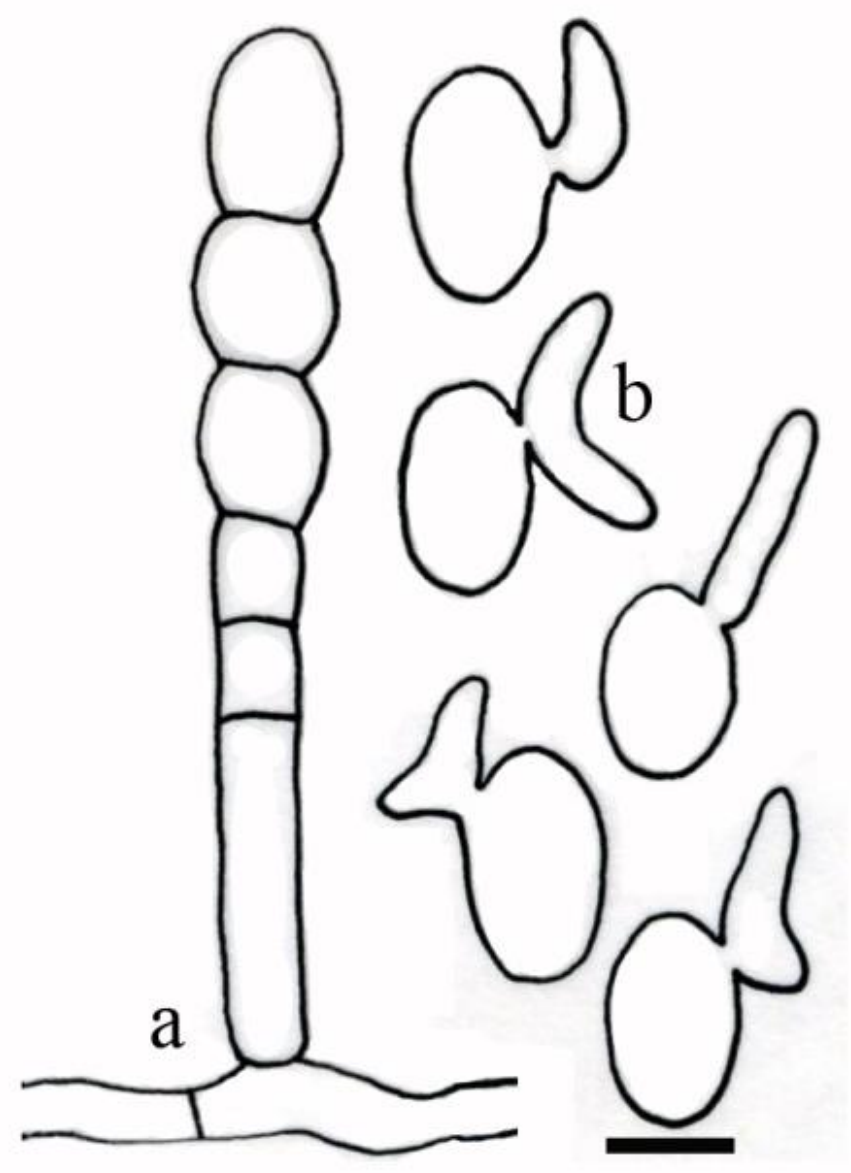

Fig. 5 - Podosphaera sp. on Raphistemma pulchellum. a conidiophore. b conidia with germ tubes. - Bar $=20 \mu \mathrm{m}$.

6. Podosphaera sp. on Aster sp.

Fig. 6

Mycelium amphigenous, thin, white, effuse or in irregular patches, persistent; hyphae at first hyaline, later turning brown, thin-walled, smooth, 4-8 $\mu \mathrm{m}$ wide; hyphal appressoria indistinct; conidiophores arising from the upper surface of superficial hyphae or mother cells, erect, straight; foot cells cylindrical, (34.5-)53-62(-70) $\times(8-) 9-11(-12) \mu \mathrm{m}$, followed by $2-3$ shorter cells, forming catenescent conida; conidia ellipsoid-ovoid to doliiform, $(26-) 28-29.5(-31.5) \times(12-) 15-$ $16(-17) \mu \mathrm{m}$.

Material examined - THAILAND, Chiang Rai Province, Wiangpapao, on Aster sp. (Asteraceae), 6 January 2016, J. Meeboon, MUMH6708. 
Notes - Podosphaera fusca is well known as a PM fungus on various host plants including Aster species worldwide (Braun \& Cook et al. 2012). Shin (1988) reported Po. fusca on Aster sp. in Korea. The morphological observation suggested that the PM on Aster of Thailand belongs to genus Podosphaera. This is the first record of PM on Aster sp. in Thailand.

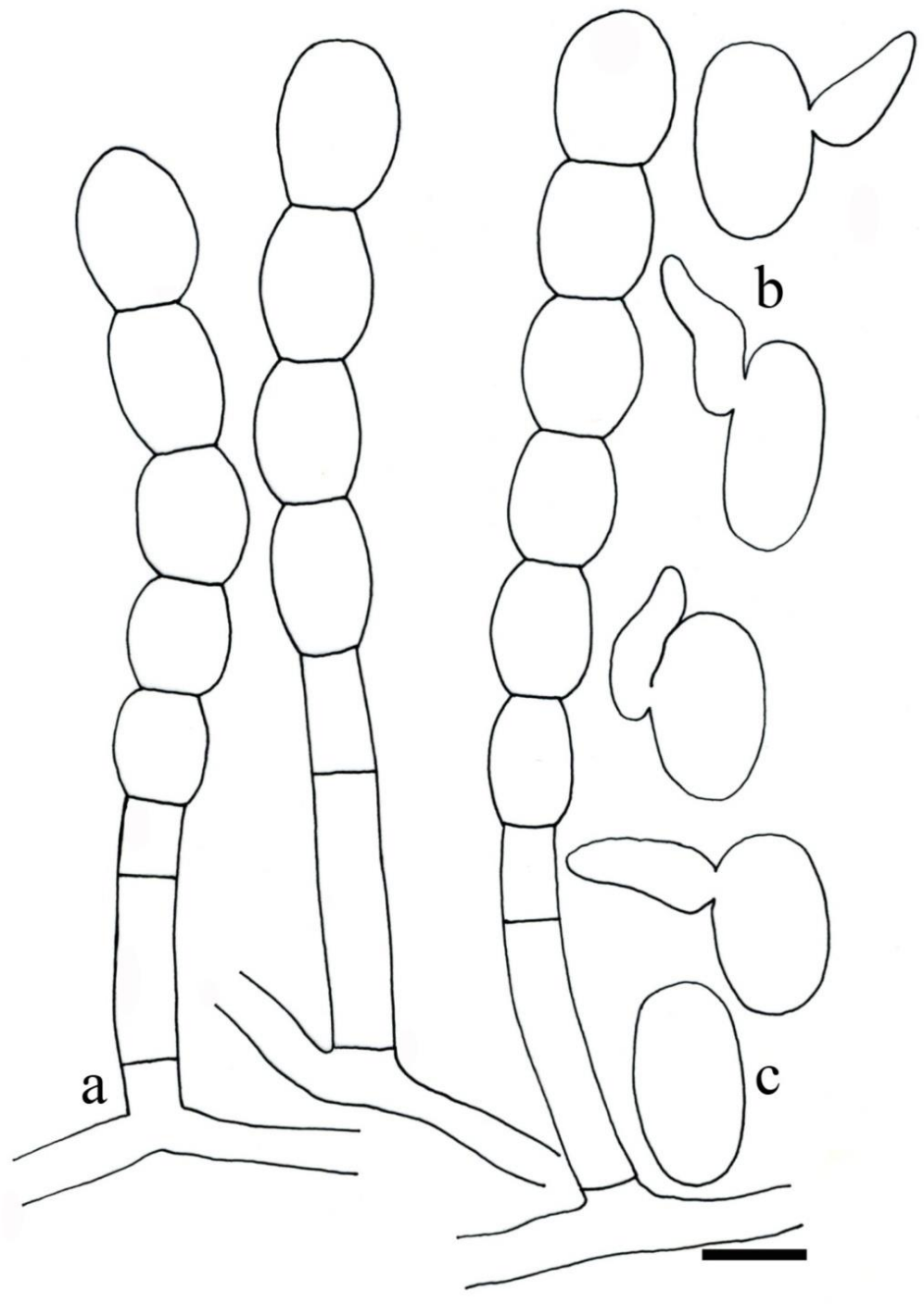

Fig. 6 - Podosphaera sp. on Aster sp. a conidiophores. b germ tubes. c conidia. - Bar $=20 \mu \mathrm{m}$.

7. Podosphaera sp. on Zinnia elegans

Fig. 7

Mycelium amphigenous, mainly epiphyllous, effuse or in patches, evanescent to persistent; hyphae hyaline, later gradually turning brown, 5-8 $\mu \mathrm{m}$ wide, walls somewhat thickened; hyphal appressoria indistinct, sometimes slightly nipple-shaped; conidiophores arising from the upper surface of hyphal mother cells, erect, straight; foot cells cylindrical, $(25.5-) 43-71(-85) \times(9-) 11-$ 13(-14) $\mu \mathrm{m}$, followed by $1-3$ shorter cells, forming catenescent conidia; conidia ellipsoid to ovoid or doliiform, $(26-) 28.5-31(-35) \times(14-) 15-17(-18) \mu \mathrm{m}$, with fibrosin bodies; germ tubes \pm lateral, simple to forked, short (brevitubus-subtype of the Podosphaera-type).

Material examined - THAILAND, Sukhothai Province, on Zinnia elegans L. (Asteraceae), 5 February 2002, S. Kom-un, MUMH1797.

Notes - Golovinomyces spadiceus (Berk. \& M.A. Curtis) U. Braun and O. erysiphoides f. zinniae Cif. have been recorded as PM species found on Z. elegans in the world (Braun \& Cook et al. 2012). However, the latter species is considered doubtful by Braun \& Cook (2012). In addition, Po. fusca is also known as a PM fungus on various host plants including Zinnia species (Braun \& 
Cook et al. 2012). Based on the general morphological characteristics of the PM on Z. elegans, this fungus belongs to the genus Podosphaera. This is the first report of Podosphaera on Z. elegans from Thailand. Molecular analysis of the PM on Z. elegans is necessary to resolve the identity of this fungus.

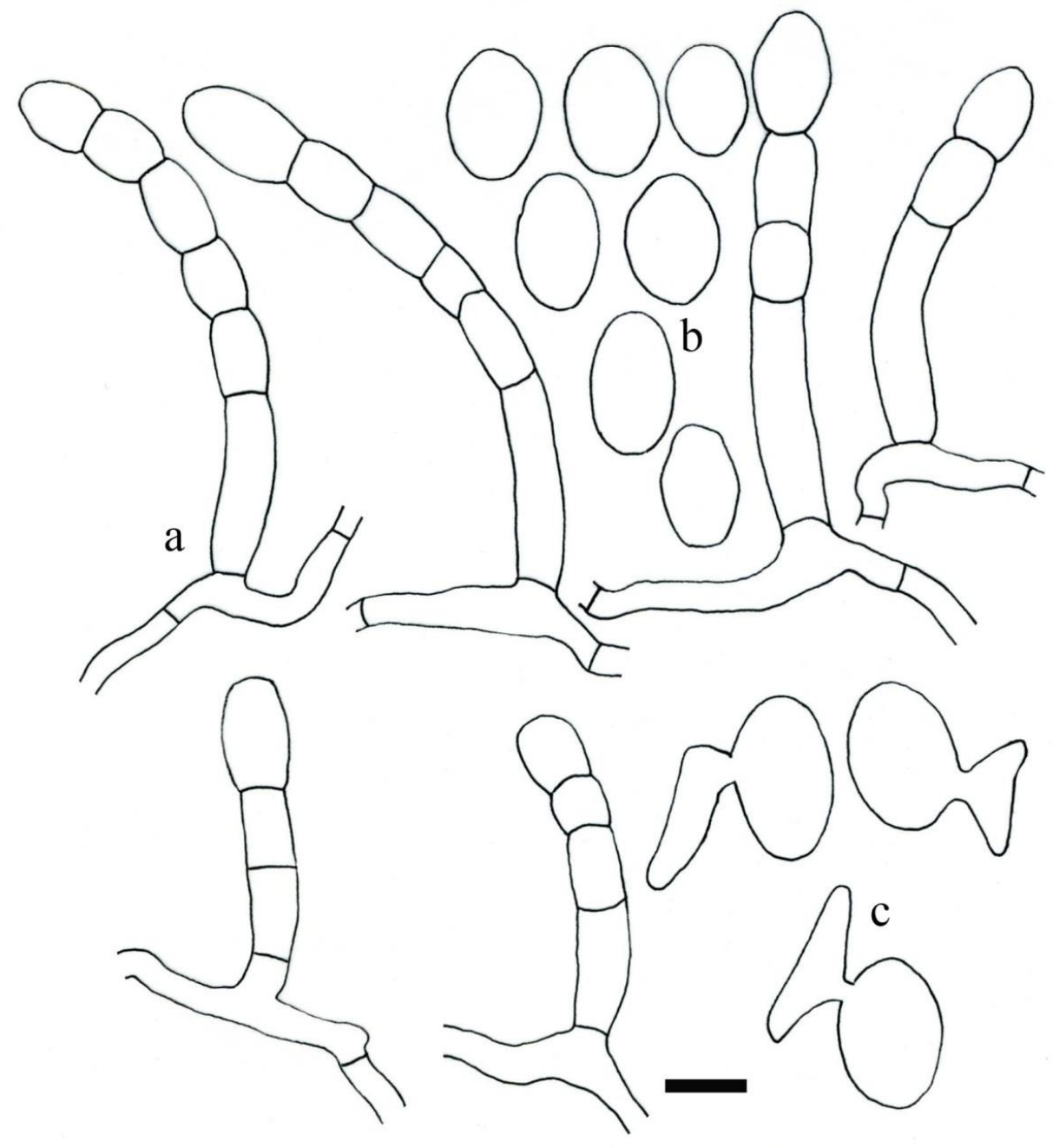

Fig. 7 - Podosphaera sp. on Zinnia elegans. a conidiophores. b conidia. c germ tubes. - Bar $=20$ $\mu \mathrm{m}$.

8. Podosphaera sp. on Calendula officinalis

Fig. 8

Mycelium amphigenous, white, dense, effuse or in patches, persistent; hyphae hyaline, thinwalled, 5-7 $\mu \mathrm{m}$ wide; hyphal appressoria nipple-shaped; conidiophores erect, straight, arising from the upper part of mother cells, position central to non-central, $(118-) 132 \times 174(-185) \mu \mathrm{m}$ long; foot cells cylindrical, (36-)38-55(-80) $\times(9.5-) 10-11(-12.5) \mu \mathrm{m}$, followed by $2-3$ shorter cells, forming catenescent conidia; conidia ellipsoid-ovoid, $(28-) 30-38(-40) \times(15-) 17.5-18.5(-21) \mu \mathrm{m}$.

Material examined - THAILAND, Chiang Mai Province, Mae Jo, on Calendula officinalis L. (Asteraceae), 8 December 2002, S. Kom-un, MUMH1845.

Notes - Based on the catenate conidia with fibrosin bodies, this PM belongs to the genus Podosphaera. Three PM species, viz, Po. fusca (Po. xanthii s. lat.), L. taurica s. lat. and E. cichoracearum [current name: G. cichoracearum (DC.) Heluta] have been recorded on Calendula spp. (Braun 1987, Braun \& Cook et al. 2012). In Korea, Po. fusca and E. polygoni were found on Calendula (Shin et al. 2000). The morphological features of the present fungus are in good 
agreement with Po. fusca. Molecular phylogenetic analysis is necessary to confirm the identity of the current specimen. This is the first report of PM on Cal. officinalis in Thailand.

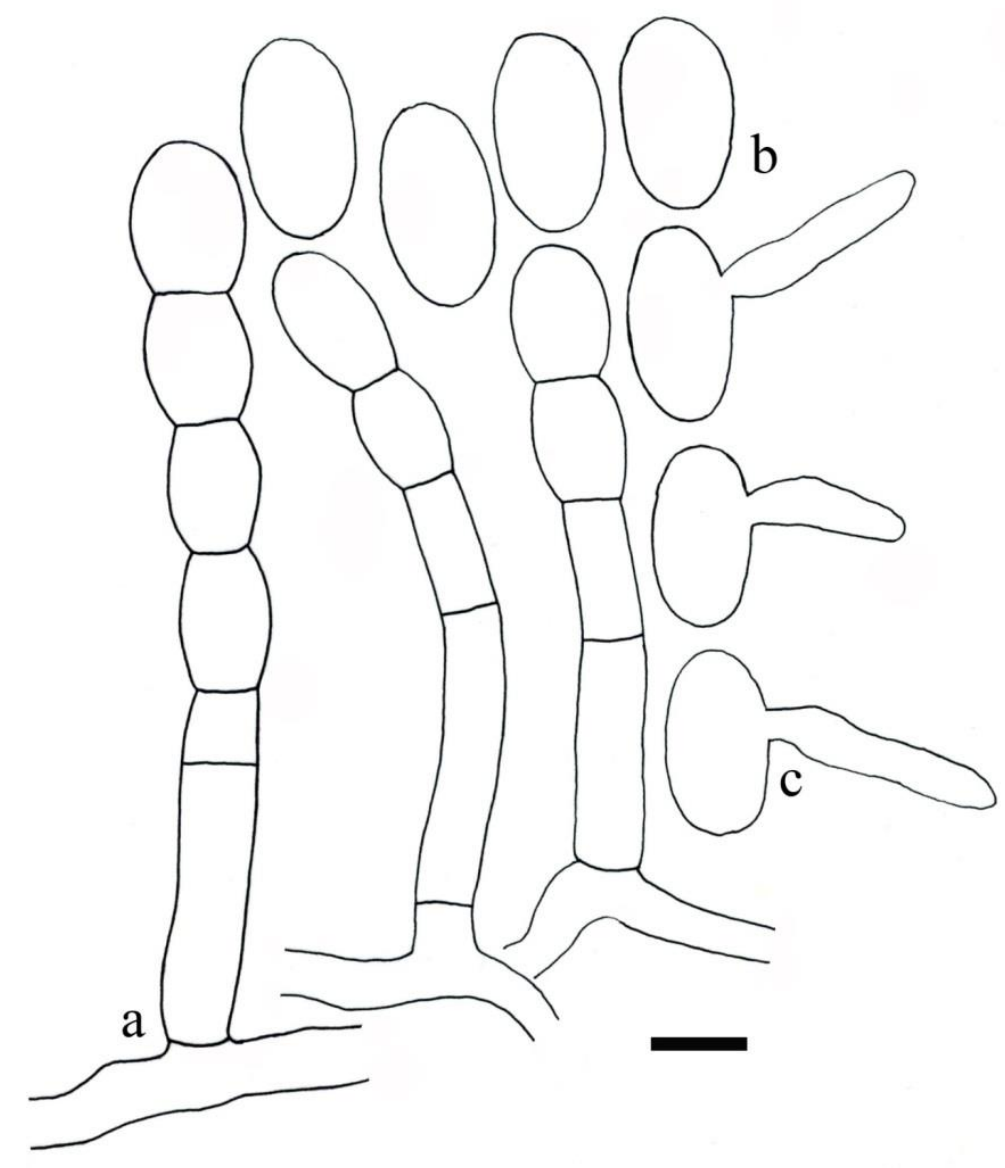

Fig. 8 - Podosphaera sp. on Calendula officinalis. a conidiophores. b conidia. c germ tubes. - Bar $=20 \mu \mathrm{m}$.

9. Podosphaera sp. on Helianthus annuus

Fig. 9

Mycelium amphigenous, mainly epiphyllous, effuse or in irregular patches, thin to dense, evanescent to \pm persistent; hyphae thin-walled, smooth or almost so, 4-8 $\mu \mathrm{m}$ wide; hyphal appressoria indistinct to slightly nipple-shaped, solitary; conidiophores arising from the upper surface of hyphal mother cells, mostly towards one end of the cell but sometimes \pm centrally, erect, about 60-180 $\mu \mathrm{m}$ long; foot cells cylindrical, 40-70 $\times 10-13 \mu \mathrm{m}$, sometimes slightly constricted at the basal septum or slightly swollen at the very base, followed by 1-2 shorter cells, forming catenescent conidia, in long chains; conidia ellipsoid-ovoid to doliiform, 25-45 × 14-22 $\mu \mathrm{m}$; germ tubes \pm lateral, simple to forked, short (brevitubus-subtype of the Podosphaera-type).

Material examined - THAILAND, Chiang Mai Province, Mae Rim, on Helianthus annuus L. (Asteraceae), 9 January 2016, J. Meeboon, MUMH6683.

Notes - The morphological characters of the current specimen are close to Po. xanthii. However, because only asexual morph was found, molecular phylogenetic analysis is necessary to determine the identity of the current specimen. The current specimen is tentatively identified as Podosphaera sp. This is the first report of Podosphaera on He. annuus from Thailand. 


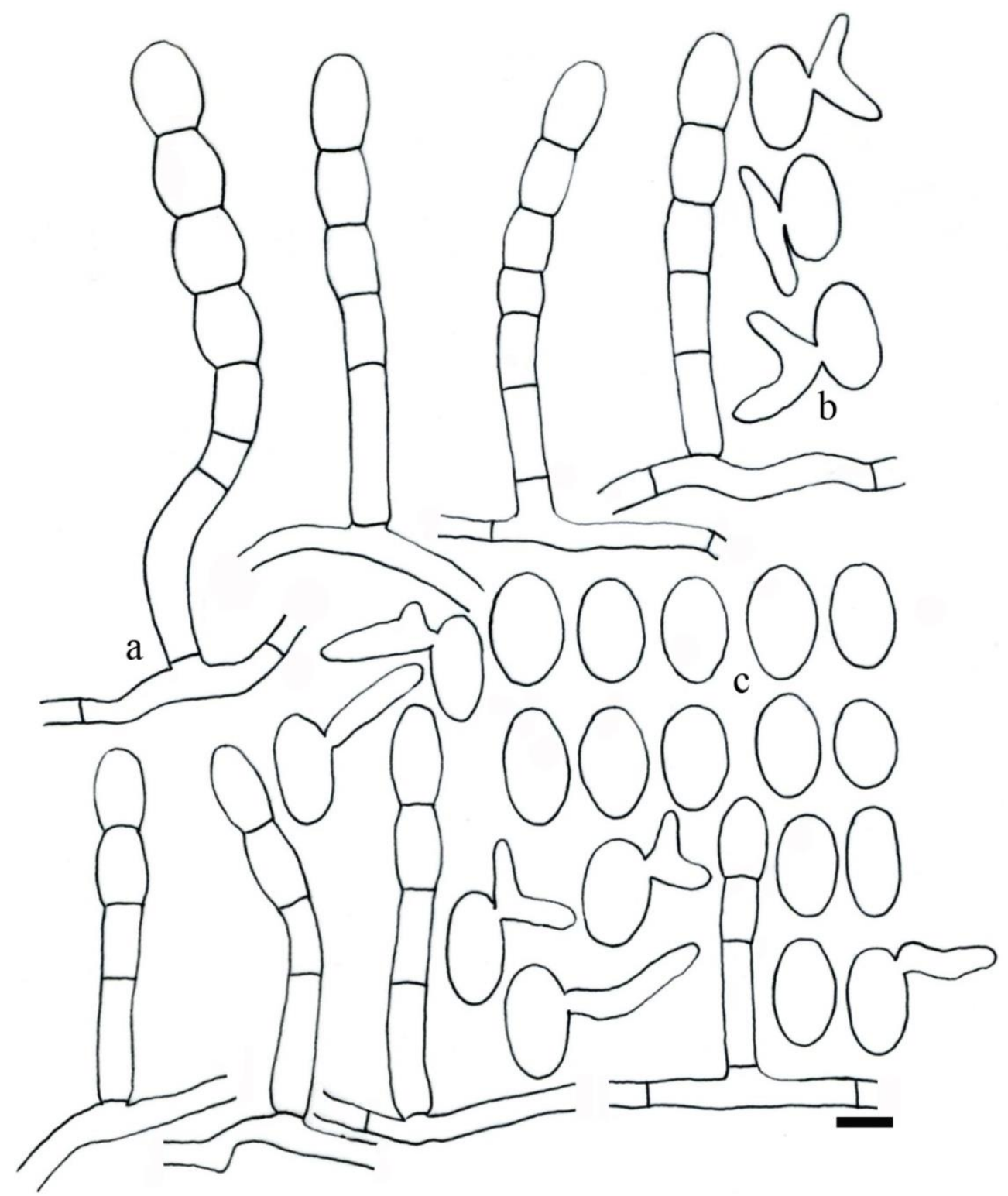

Fig. 9 - Podosphaera sp. on Helianthus annuus. a conidiophores. $\mathrm{b}$ germ tubes. $\mathrm{c}$ conidia. - Bar $=$ $20 \mu \mathrm{m}$.

10. Podosphaera sp. on Cleome viscosa

Fig. 10

Mycelium amphigenous, in irregular patches or effuse, thin to dense, evanescent to \pm persistent; hyphae thin-walled, smooth, 4-7 $\mu \mathrm{m}$ wide; hyphal appressoria indistinct to slightly nipple-shaped, solitary; conidiophores arising from the upper surface of hyphal mother cells, erect; foot cells cylindrical, $75-100 \times 12-13 \mu \mathrm{m}$, sometimes slightly constricted at the basal septum or slightly swollen at the very base, followed by 1-2 shorter cells, forming catenescent conidia; conidia ellipsoid-ovoid to doliiform, 35-40 × 18-21 $\mu \mathrm{m}$; germ tubes \pm lateral, simple to forked, short (brevitubus-subtype of the Podosphaera-type).

Material examined - THAILAND, Chiang Mai Province, Mae Rim, on Cleome viscosa DC. (Cleomaceae), 9 January 2016, J. Meeboon, MUMH3344.

Notes - Leveillula cleomis Simonyan \& Heluta, E. cruciferarum Opiz ex L. Junell, $O$. capparidacearum V.K. Pal, Akhtar, Kamal \& N. Ahmad, G. orontii and S. fuliginea have been listed as PMs on Cleome spp. (Amano 1986, Braun \& Cook et al. 2012). However, the morphological characteristics of the current specimen resemble the genus Podosphaera. Although several morphological characters of this specimen are similar to asexual morph of Po. xanthii, 
molecular analysis is necessary to determine its identity. This is the first report of Podosphaera on Cl. viscosa in Thailand.

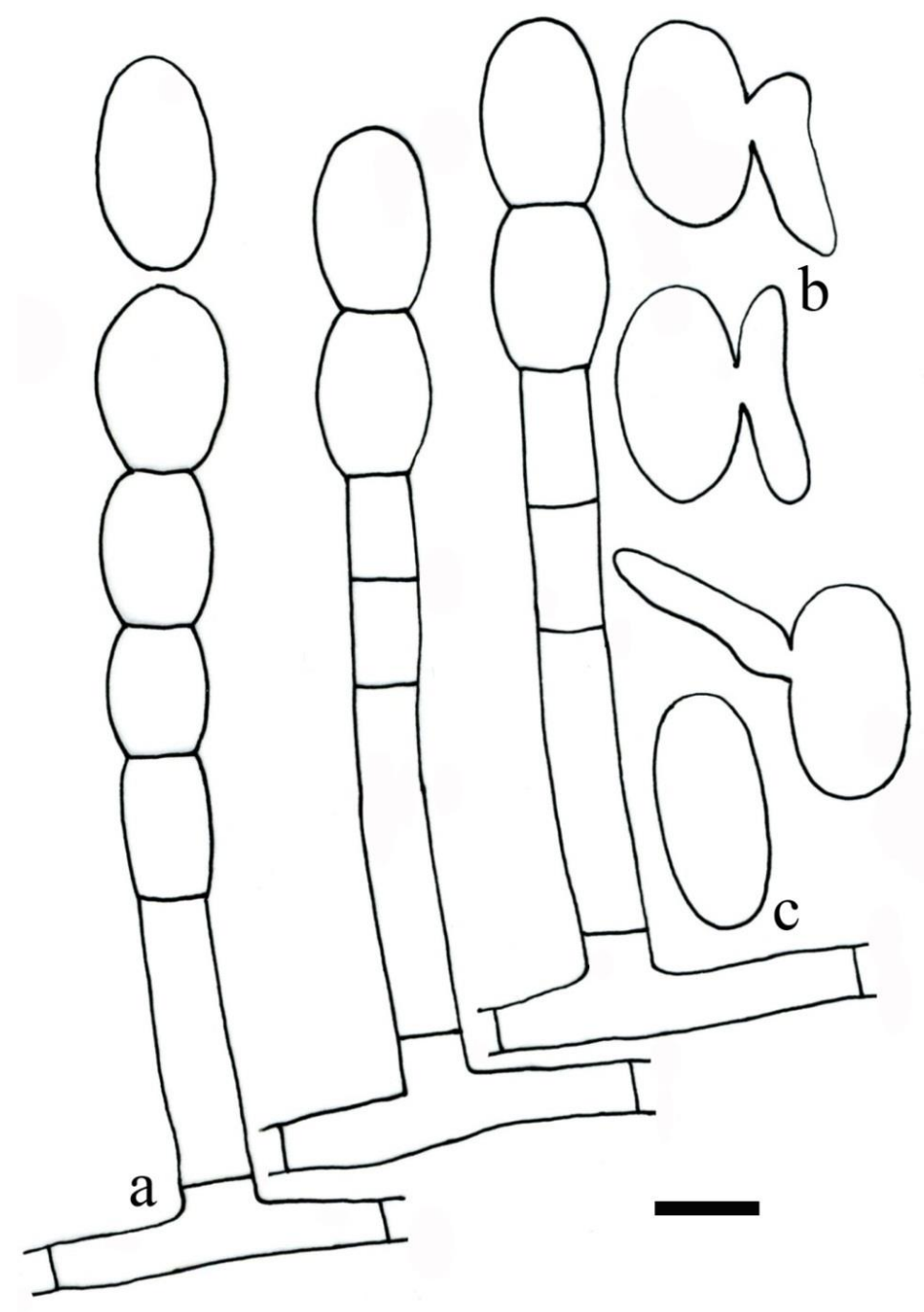

Fig. $10-$ Podosphaera sp. on Cleome viscosa a conidiophores. b germ tubes. $\mathrm{c}$ conidia. - Bar $=20$ $\mu \mathrm{m}$.

11. Podosphaera sp. on Lagenaria siceraria var. gourda

Fig. 11

Mycelium amphigenous, in irregular patches or effuse, thin to dense, evanescent to \pm persistent; hyphae thin-walled, smooth or almost so, 5-8 $\mu \mathrm{m}$ wide; hyphal appressoria indistinct to slightly nipple-shaped, solitary; conidiophores arising from the upper surface of hyphal mother cells, mostly towards one end of the cell but sometimes \pm centrally, erect; foot cells cylindrical, 45 $97 \times 9-13 \mu \mathrm{m}$, sometimes slightly constricted at the basal septum or slightly swollen at the very base, followed by 1-3 shorter cells, forming catenescent conidia, in long chains; conidia ellipsoidovoid, $27-42 \times 13-22 \mu \mathrm{m}$.

Material examined - THAILAND, Chiang Mai Province, Mae Rim, on Lagenaria siceraria (Molina) Standl. var. gourda (Cucurbitaceae),19 January 2016, J. Meeboon, MUMH6709.

Notes - In the latest monograph of Erysiphales (Braun \& Cook et al. 2012), Po. xanthii and G. cucurbitacearum (R.Y. Zheng \& G.Q. Chen) Vakal. \& Kliron. have been recorded as PMs on the genus Lagenaria. The present fungus resembles morphological characteristics of Podosphaera. Because no sexual morph was found in this specimen, it is difficult to assign this specimen as $P o$. xanthii. Molecular phylogenetic analyses could not be carried out due to failure of DNA extraction. 
Thus, this specimen is tentatively assigned as Podosphaera sp. This is the first report of PM on $L$. siceraria var. gourda in Thailand.

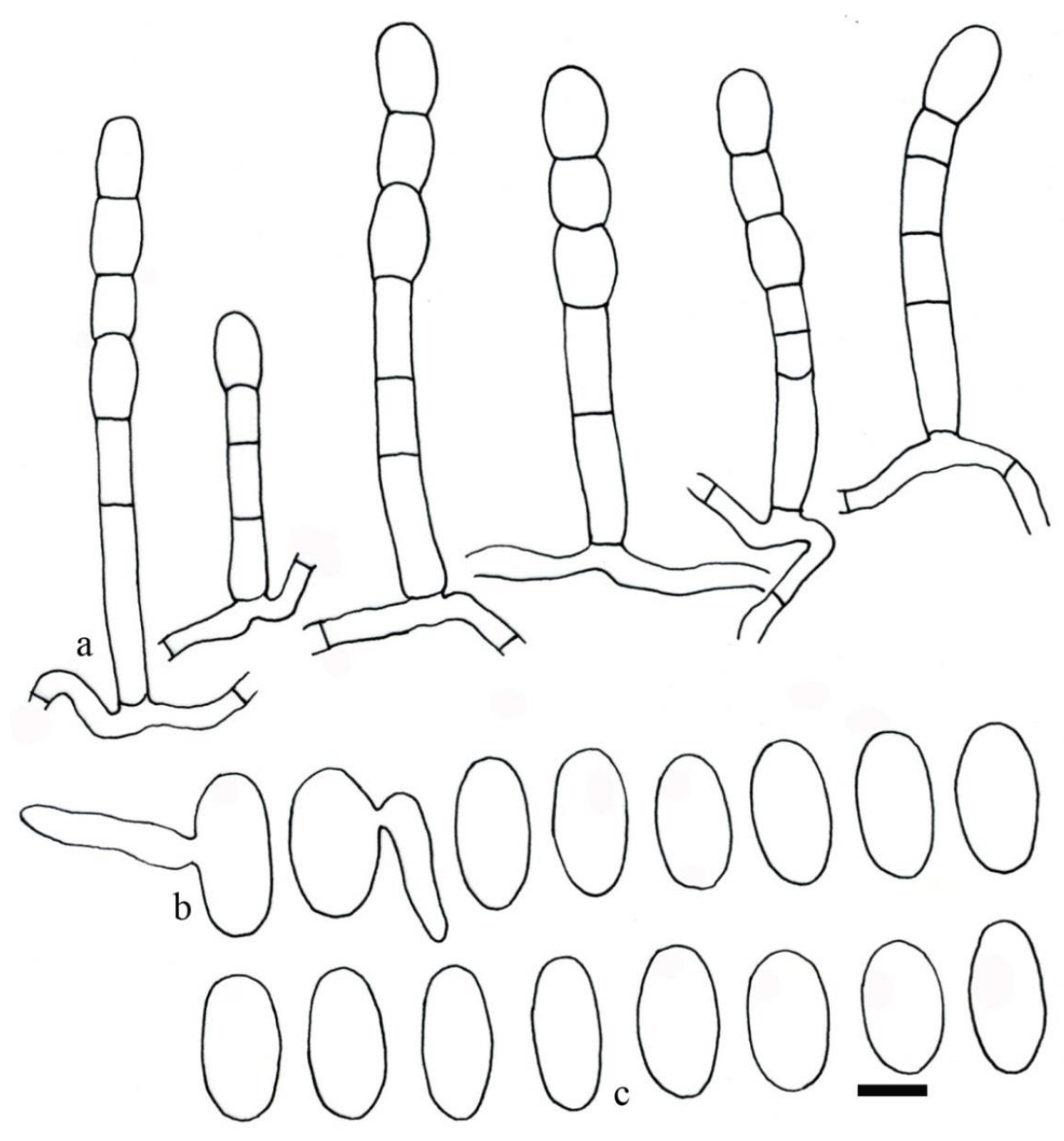

Fig. 11 - Podosphaera sp. on Lagenaria siceraria var. gourda. a conidiophores. b germ tubes. c conidia. - Bar $=20 \mu \mathrm{m}$.

\section{Podosphaera sp. on Cucumis melo}

Fig. 12

Mycelium amphigenous, effused, sub-evanescent; hyphae substraight to somewhat wavy, branching at right or narrow angle, with a septum near the branching point; appressoria indistinct, sometimes slightly nipple-shaped, single; conidiophores erect, single or occasionally two on a hyphal cell, arising from the upper part of mother cells, position central to non-central; foot cells cylindric, forming catenescent conidia, with a basal septum at the branching point of the mycelium; conidia ellipsoid-ovoid, containing conspicuous fibrosin bodies.

Material examined - THAILAND, Chiang Mai Province, Mae Rim, on Cucumis melo L. (Cucurbitaceae), 9 January 2014, J. Meeboon, MUMH3707.

Notes - Erysiphe actinostemmatis U. Braun, E. pisi var. pisi, E. polygoni DC., G. cichoracearum, G. orontii and Po. xanthii are PM species found on C. melo (Farr \& Rossman 2010, Braun \& Cook et al. 2003). Among them, Po. xanthii is the most common powdery mildew on this host (Farr \& Rossman et al. 2010). The asexual morph of the present fungus resembles the genus Podosphaera. Podosphaera xanthii has been reported on various cucurbitaceous species around the world (Braun \& Cook et al. 2012). Because the current specimen did not produce sexual morph, it is difficult to determine the species name of this specimen. Molecular analysis is 
necessary to determine the identity of the PM on C. melo in Thailand. This is the first record of Podosphaera on C. melo from Thailand.

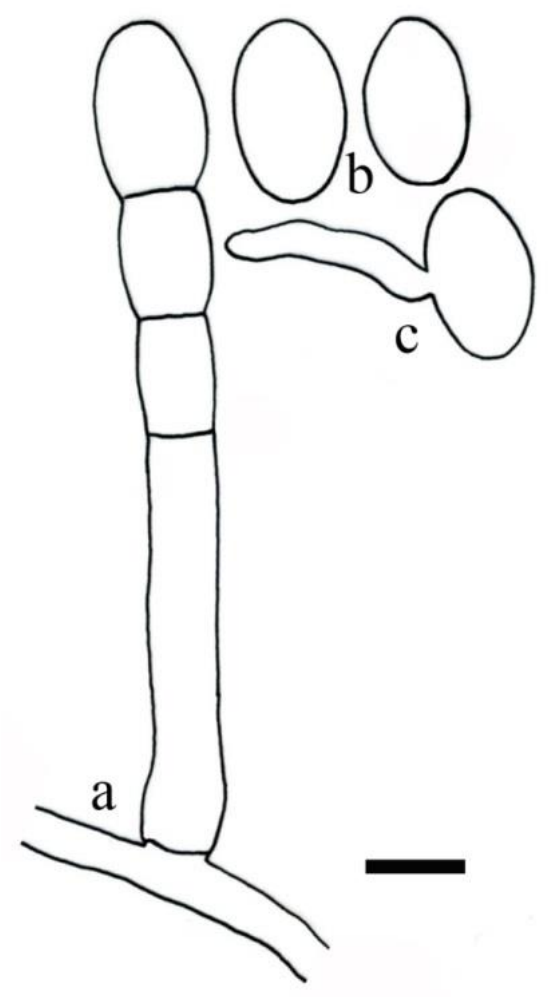

Fig. 12 - Podosphaera sp. on Cucumis melo. a conidiophore. b conidia. c germ tube. - Bar $=20$ $\mu \mathrm{m}$.

\section{Podosphaera sp. on Cucurbita moschata}

Mycelium mostly amphigenous, effuse or in irregular thick patches, evanescent to \pm persistent; hyphae straight to sinuous, hyaline, thin-walled, 8-10 $\mu \mathrm{m}$ wide, mostly lacking pigmented persistent hyphae; hyphal appressoria nipple-shaped; conidiophores arising from the upper surface of hyphal mother cells, usually towards one end of cell, erect, $(115-) 152-170(-200)$ $\mu \mathrm{m}$ long; foot cells cylindrical, (32.5-)37.5-62.5(-72.5) $\times 10-12.5 \mu \mathrm{m}$, followed by 1-2 shorter cells, forming catenescent conidia; conidia ellipsoid-ovoid to doliiform, $(28-) 32.5-33(-36) \times(16-$ )18-20(-22) $\mu \mathrm{m}$, containing conspicuous fibrosin bodies.

Material examined - THAILAND, Chiang Mai Province, Mae Rim, on Cucurbita moschata Duchesne (Cucurbitaceae), 6 January 2002, S. Kom-un, MUMH1836.

Notes - The asexual morph indicates that this specimen belongs to the genus Podosphaera. Three Podosphaera species, i.e., Po. fusca, Po. fuliginea and Po. macularis have been recorded on $\mathrm{Cu}$. moschata worldwide (Farr \& Rossman et al. 2010). Morphologically, this fungus is similar to the asexual morph of Po. xanthii, which has been reported on various host plants including various Cucurbita species worldwide (Braun \& Cook 2012). However, molecular analysis is necessary to confirm the morphological identification. In Thailand, G. biocellatus (Ehrenb.) Heluta is recorded as PM found on $\mathrm{Cu}$. moschata (Giatgong et al. 1980). This is the first report of Podosphaera on $\mathrm{Cu}$. moschata in Thailand. 


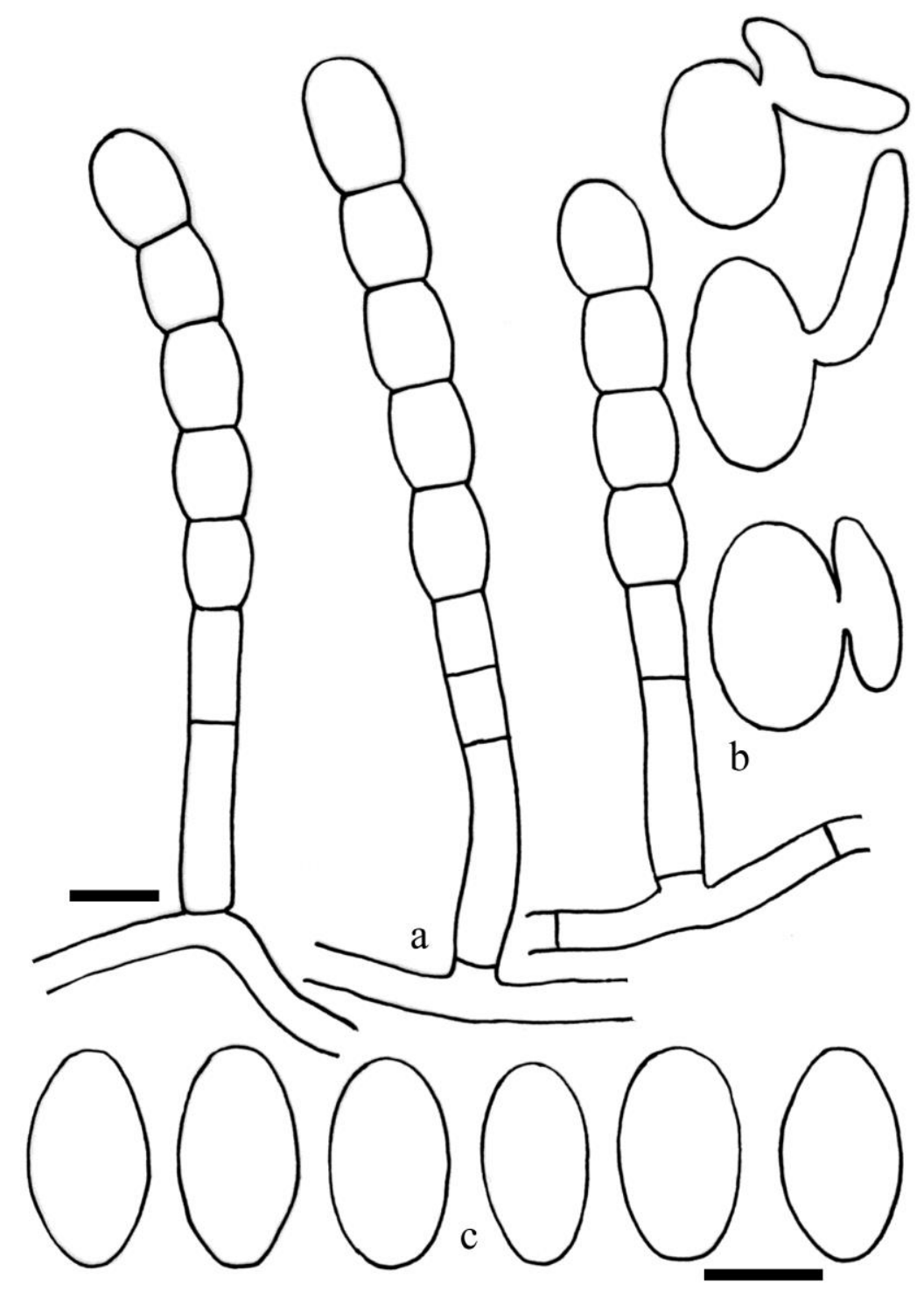

Fig. 13 - Podosphaera sp. on Cucurbita moschata. a conidiophores. b germ tubes. c conidia. - Bar $=20 \mu \mathrm{m}$.

14. Podosphaera sp. on Coccinia grandis

Fig. 14

Mycelium amphigenous, in irregular white patches or effuse, thin to dense, evanescent to \pm persistent; hyphae thin-walled, smooth, 4-6 $\mu \mathrm{m}$ wide; hyphal appressoria indistinct to slightly nipple-shaped, solitary; conidiophores arising from the upper surface of hyphal mother cells, erect or slightly curved; foot cells cylindrical, 40-70 $\times 12-13 \mu \mathrm{m}$, sometimes slightly constricted at the basal septum or slightly swollen at the very base, followed by $0-2$ shorter cells, forming catenescent conidia; conidia ellipsoid-ovoid to doliiform, $(30-) 35-40(-45) \times(18-) 20-22(-24) \mu \mathrm{m}$; germ tubes \pm lateral, simple to forked, short (brevitubus-subtype of the Podosphaera-type).

Material examined - THAILAND, Chiang Rai Province, Wiangpapao, on Coccinia grandis (L.) Voigt (Cucurbitaceae), 5 January 2016, J. Meeboon, MUMH6613.

Notes - Podosphaera fuliginea (in Bangladesh) and E. actinostemmatis U. Braun (in Japan and China) are PM fungi found on Co. grandis in the world (Amano 1986, Braun \& Cook et al. 2012). The morphological characteristics of the current specimen resemble the genus Podosphaera. This is the first record of the genus Podosphaera found on Co. grandis (Cucurbitaceae) in Thailand. Podosphaera xanthii has been commonly reported from cucurbitaceous plants. We did not obtain DNA sequence of the current specimen, but the phylogenetic analysis based on ITS 
sequence of other Podosphaera on Cucurbitaceae from Southeast Asia (e.g. C. sativus, Cu. pepo, etc.) showed that these sequences nested in the clade of Po. xanthii.

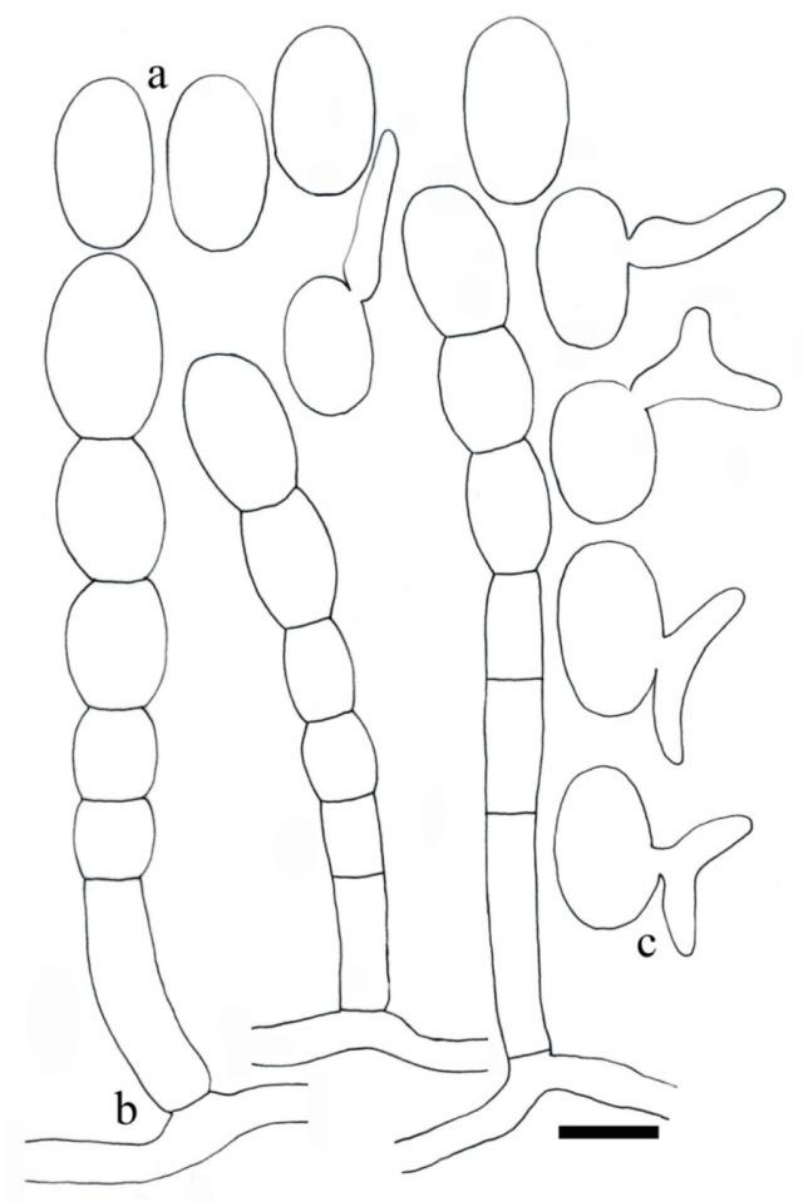

Fig. $14-$ Podosphaera sp. on Coccinia grandis. a conidia. $\mathrm{b}$ conidiophores. $\mathrm{c}$ germ tubes. - Bar $=$ $20 \mu \mathrm{m}$.

\section{Podosphaera sp. on Leucas decemdentata}

Mycelium on stems (caulicolous) and leaves (foliicolous), amphigenous, in dense patches, white; hyphae 3-6 $\mu \mathrm{m}$ wide; appressoria nipple-shaped; conidiophores erect, arising from the upper surface of hyphal mother cells, about 80-155 $\mu \mathrm{m}$ long; foot cells straight, cylindrical about 45-80 $\times$ 8-10 $\mu \mathrm{m}$, followed by shorter cells, forming catenescent conidia; conidia ellipsoid to obovate, 25$35 \times 9-12 \mu \mathrm{m}$, with fibrosin bodies; germ tubes \pm lateral, simple to forked, short (brevitubussubtype of the Podosphaera-type).

Material examined - THAILAND, Petchaboon Province, Num Nao National Park, on Leucas decemdentata (Willd.) Sm. (Lamiaceae), 31 January 2004, J. Meeboon, MUMH3317.

Notes - This specimen is the first find of Podosphaera on the plant genus Leucas in the world. In the latest monograph of the Erysiphales (Braun \& Cook et al. 2012), N. galeopsidis (DC.) $\mathrm{U}$. Braun and its anamorph is the only PM species found on this plant worldwide. Further study in molecular analysis is important to determine the identity of this specimen. 


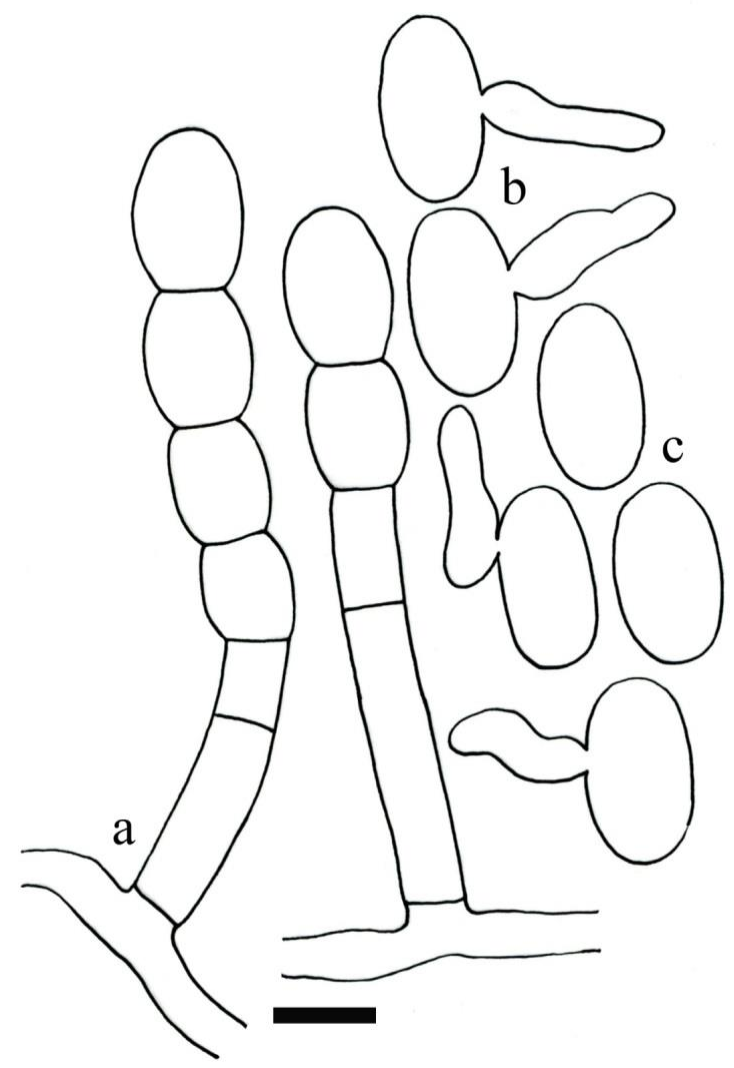

Fig. 15 - Podosphaera sp. on Leucas decemdentata. a conidiophores. b germ tubes. c conidia. Bar $=20 \mu \mathrm{m}$.

\section{Podosphaera sp. on Hibiscus mutabilis}

Fig. 16

Mycelium amphigenous, thin, in patches or effuse, evanescent to \pm persistent, usually inconspicuous; hyphae smooth or almost so, 5-8 $\mu \mathrm{m}$ wide, thin-walled; hyphal appressoria indistinct; conidiophores straight, erect, arising from the upper surface of hyphal mother cells, usually centrally, occasionally towards one end of the cell, up to $220 \mu \mathrm{m}$ long; foot cells cylindrical, about $40-65 \times 9-12 \mu \mathrm{m}$, followed by 1-2 shorter cells, forming catenescent conidia; conidia ellipsoid-ovoid, (28-)33-38(-41) $\times(15-) 18-20(-22) \mu \mathrm{m}$, containing fibrosin body; germ tubes \pm lateral, simple to forked, short (brevitubus-subtype of the Podosphaera-type).

Material examined - THAILAND, Chiang Mai Province, Mae Rim, on Hibiscus mutabilis L. (Malvaceae), 9 January 2016, J. Meeboon, MUMH3752.

Notes - Podosphaera fuliginea, Po. hibiscicola (Z.Y. Zhao) U. Braun \& S. Takam. on Hi. mutabilis, F. abelmoschi (Thüm.) U. Braun \& R.T.A. Cook on Hi. esculenthus, and F. balakrishnanii (Hosag., Vijay., Udaiyan \& Manian) U. Braun \& R.T.A. Cook on Hibiscus spp. have been recorded as PMs from the tribe Cystotheceae worldwide (Amano 1986, Braun \& Cook et al. 2012). The morphological characters of the current specimen are more similar to $F$. abelmoschi (Thüm.) U. Braun \& R.T.A. Cook than to F. balakrishnani (Hosag., Vijay., Udaiyan \& Manian) U. Braun \& R.T.A. Cook. Although Po. hibiscicola (Z.Y. Zhao) U. Braun \& S. Takam. is recorded on the same host, we could not compare the current species with Po. hibiscicola due to lack of description of asexual morph. Therefore, the current specimen is identified as Podosphaera sp. This is the first report of Podosphaera on Hi. mutabilis in Thailand. 


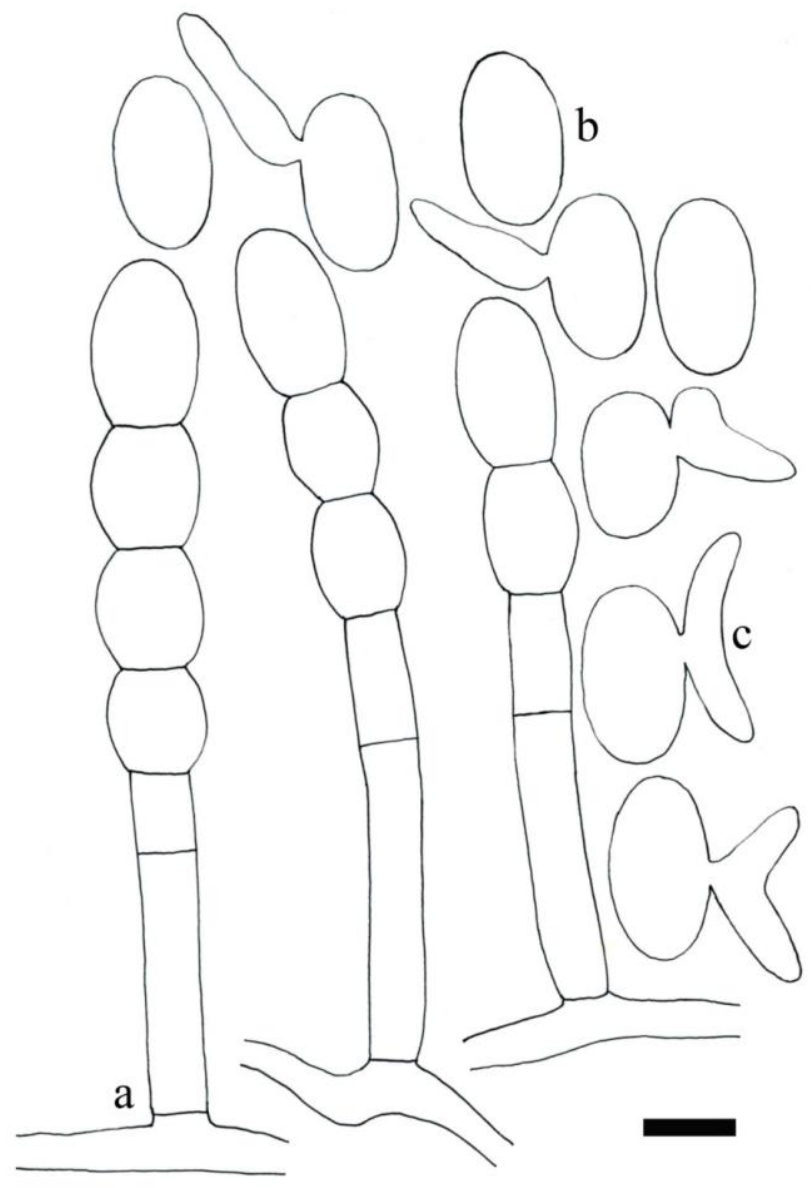

Fig. 16 - Podosphaera sp. on Hibiscus mutabilis. a conidiophores. b conidia. c germ tubes. - Bar $=$ $20 \mu \mathrm{m}$.

17. Podosphaera sp. on Hibiscus sabdariffa

Fig. 17

Mycelium amphigenous, in irregular patches or effuse, thin to dense, evanescent to \pm persistent; hyphae thin-walled, smooth, 5-6 $\mu \mathrm{m}$ wide; hyphal appressoria indistinct to slightly nipple-shaped, solitary; conidiophores erect or slightly curved, arising from the upper surface of hyphal mother cells; foot cells cylindrical, 50-85 × 12-14 $\mu \mathrm{m}$, sometimes slightly constricted at the basal septum or slightly swollen at the very base, followed by 1-2 shorter cells, forming catenescent conidia; conidia ellipsoid-ovoid to doliiform, (33-)35-38(-40) × 19-20(-21) $\mu \mathrm{m}$; germ tubes \pm lateral, simple to forked, short (brevitubus-subtype of the Podosphaera-type).

Material examined - THAILAND, Chiang Mai Province, Mae Rim, on Hibiscus sabdariffa L. (Malvaceae), 9 January 2016, J. Meeboon, MUMH3715.

Notes - Fibroidium abelmoschi (Thüm.) U. Braun \& R.T.A. Cook on Hi. esculentus from Egypt (Africa) and F. balakrishnanii (Hosag., Vijay., Udaiyan \& Manian) U. Braun \& R.T.A. Cook on Hibiscus sp. from India (Asia) have been recorded on this plant (Braun \& Cook et al. 2012). However, it is difficult to differentiate the current specimen from $F$. abelmoschi and $F$. balakrishnanii based on morphological characteristics. Thus, it is necessary to use use molecular analysis in determining the status of the current specimen. This is the first report of Podosphaera on Hi. sabdariffa in the world. 


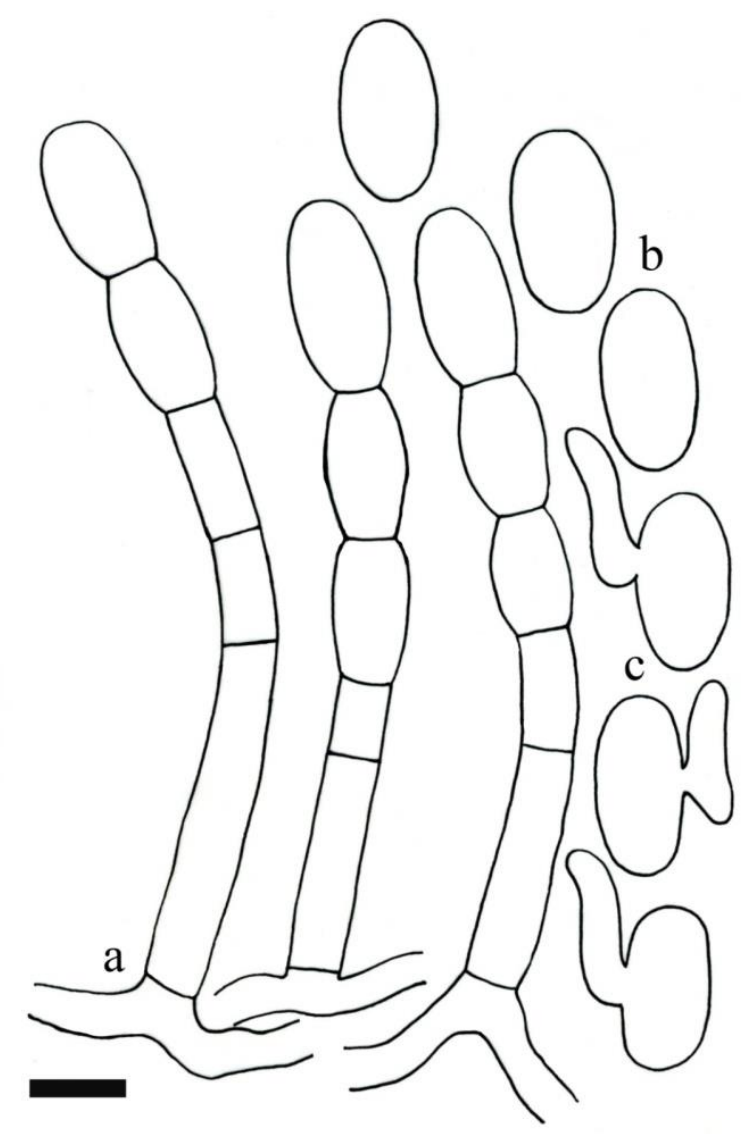

Fig. 17 - Podosphaera sp. on Hibiscus sabdariffa. a conidiophores. b conidia. c germ tubes. - Bar $=20 \mu \mathrm{m}$.

18. Podosphaera sp. on Kydia sp.

Fig. 18

Mycelium amphigenous, in irregular patches or effuse, thin to dense, evanescent to \pm persistent; hyphae thin-walled, smooth, 4-6 $\mu \mathrm{m}$ wide; hyphal appressoria indistinct to slightly nipple-shaped, solitary; conidiophores erect or slightly curved, arising from the upper surface of hyphal mother cells; foot cells cylindrical, 60-95 × 12-13 $\mu \mathrm{m}$, sometimes slightly constricted at the basal septum or slightly swollen at the very base, followed by 1-2 shorter cells, forming catenescent conidia; conidia ellipsoid-ovoid to doliiform, (35-)40-42(-43) $\times 19-22 \mu \mathrm{m}$; germ tubes \pm lateral, simple to forked, short (brevitubus-subtype of the Podosphaera-type).

Material examined - THAILAND, Chiang Mai Province, Mae Rim, on Kydia sp. (Malvaceae), 9 January 2016, J. Meeboon, MUMH3298.

Notes - Erysiphe kydiae-calycinae (R.K. Verma, Chand \& Kamal) U. Braun \& S. Takam. from Nepal (Asia) and P. kydiae (Hosag.) U. Braun \& R.T.A. Cook from India have been recorded as PMs on plant genus Kydia (Braun \& Cook et al. 2012). Therefore, this is is the first report of the genus Podosphaera found on Kydia in the world. 


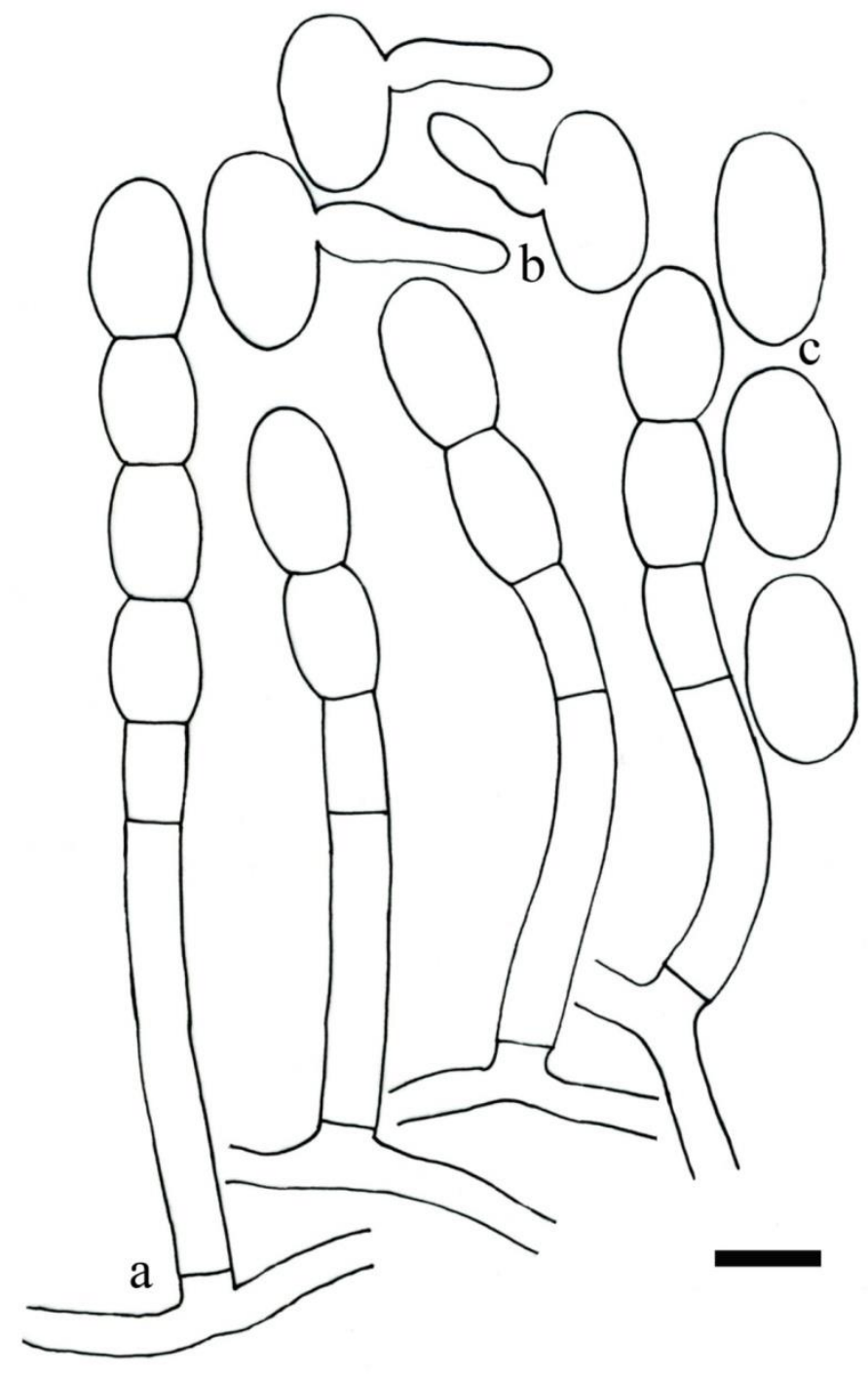

Fig. 18 - Podosphaera sp. on Kydia sp. a conidiophores. b germ tubes. c conidia. - Bar $=20 \mu \mathrm{m}$.

\section{Podosphaera sp. on Sesamum indicum}

Fig. 19

Mycelium amphigenous, effuse or forming patches, confluent, dense, white, evanescent to persistent; hyphae hyaline, thin-walled, smooth, 5-8 $\mu \mathrm{m}$ wide; hyphal appressoria nipple-shaped; conidiophores straight, erect, arising from the upper surface of superficial hyphae, about 100-190 $\mu \mathrm{m}$ long; foot cells straight to slightly curved, cylindrical, $50-70 \times 13-16 \mu \mathrm{m}$, followed by $1-2$ shorter cells, forming catenescent conidia; conidia ellipsoid-ovoid to cylindrical or doliiform, (2528-35(-42) $\times 15-20 \mu \mathrm{m}$, with fibrosin bodies; germ tubes \pm lateral, simple to forked, short (brevitubus-subtype of the Podosphaera-type).

Material examined - THAILAND, Chiang Mai Province, Mae Rim, on Sesamum indicum L. (Pedaliaceae), 9 January 2016, J. Meeboon, MUMH3748.

Notes - Podospahera xanthii, Po. fuliginea and F. sesami U. Braun \& R.T.A. Cook are PM fungi found on the genus Sesamum worldwide (Thaung 2007, Braun \& Cook et al. 2012). Analysis of molecular phylogeny is necessary to determine the identity of the current specimen. This is the first report of Podosphaera on Se. indicum in Thailand. 


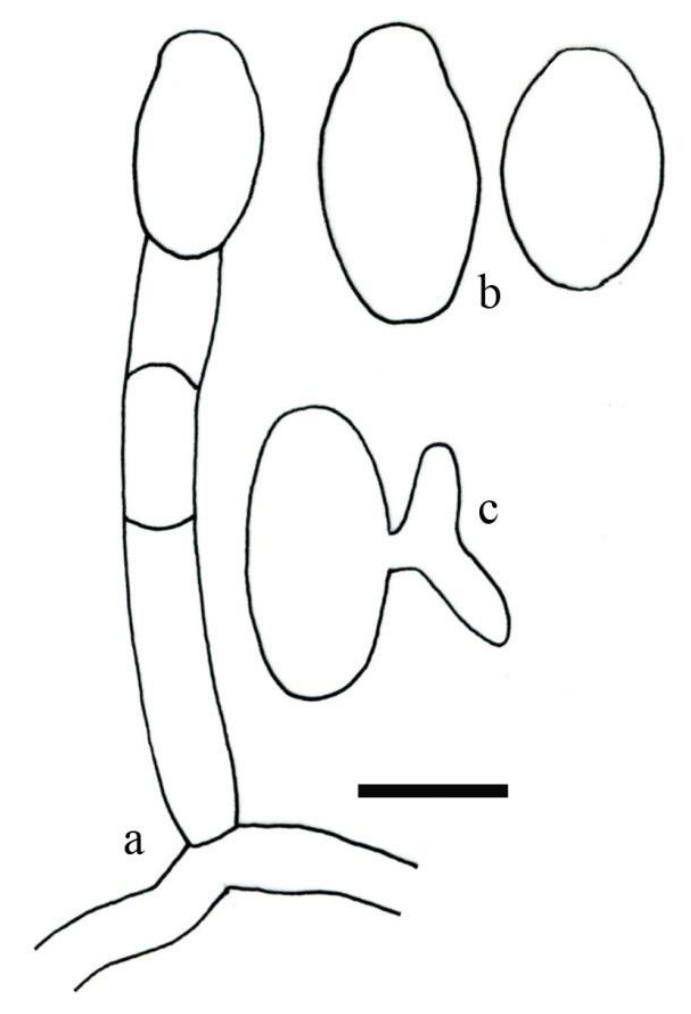

Fig. 19 - Podosphaera sp. on Sesamum indicum. a conidiophore. $\mathrm{b}$ conidia. c germ tube - Bar $=20$ $\mu \mathrm{m}$.

20. Podosphaera sp. on Prunus persica

Fig. 20

Mycelium amphigenous, persistent, in dense patches; hyphal cells 4-6 $\mu \mathrm{m}$, branching at right angles, with a septum at the branching point; hyphal appressoria nipple-shaped; conidiophores arising from the upper surface of hyphal mother cells, position central to non-central, (90-221) $\mu \mathrm{m}$ long; foot cells cylindrical, (30-)35-65(-75) $\times(8-) 10-11(-11.5) \mu \mathrm{m}$, followed by $1-2$ shorter cells, forming catenescent conidia; conidia ellipsoid-ovoid to doliiform, $(28-) 29-33(-34.5) \times(15-) 15.5(-$ 19) $\mu \mathrm{m}$, containing conspicuous fibrosin bodies.

Material examined - THAILAND, Chiang Mai Province, Mae Rim, on Prunus persica (L.) Batsch (Rosaceae), 9 January 2016, J. Meeboon, MUMH1856.

Notes - Podosphaera leucotricha (Ellis \& Everh.) E.S. Salmon, Po. clandestina (Wallr. : Fr.) Lév., Po. pannosa (Wallr. : Fr.) de Bary and Po. tridactyla (Wallr.) de Bary have been recorded on various host plants including Prunus s. lat. (Farr \& Rossman 2010, Braun \& Cook et al. 2012). These works provided additional information of taxonomic value by describing the mycelial morphology and conidiophore position on mother cell. However, Takamatsu (2010) considered that Po. longiseta [previously included in Po. tridactyla s. lat. sensu Braun (1987)] from Pr. guyana and Pr. buergeriana (endemic to Japan) must be considered a separate species. Takamatsu (2010) noted that lectotypification of Po. longiseta from Prunus spp. is necessary due to unavailable type material. Asexual morph characteristics of the present fungus clearly resemble the genus Podosphaera. Molecular analysis is necessary to resolve the identity of this fungus to species level. This is the first report of Podosphaera on Pr. persica in Thailand. 


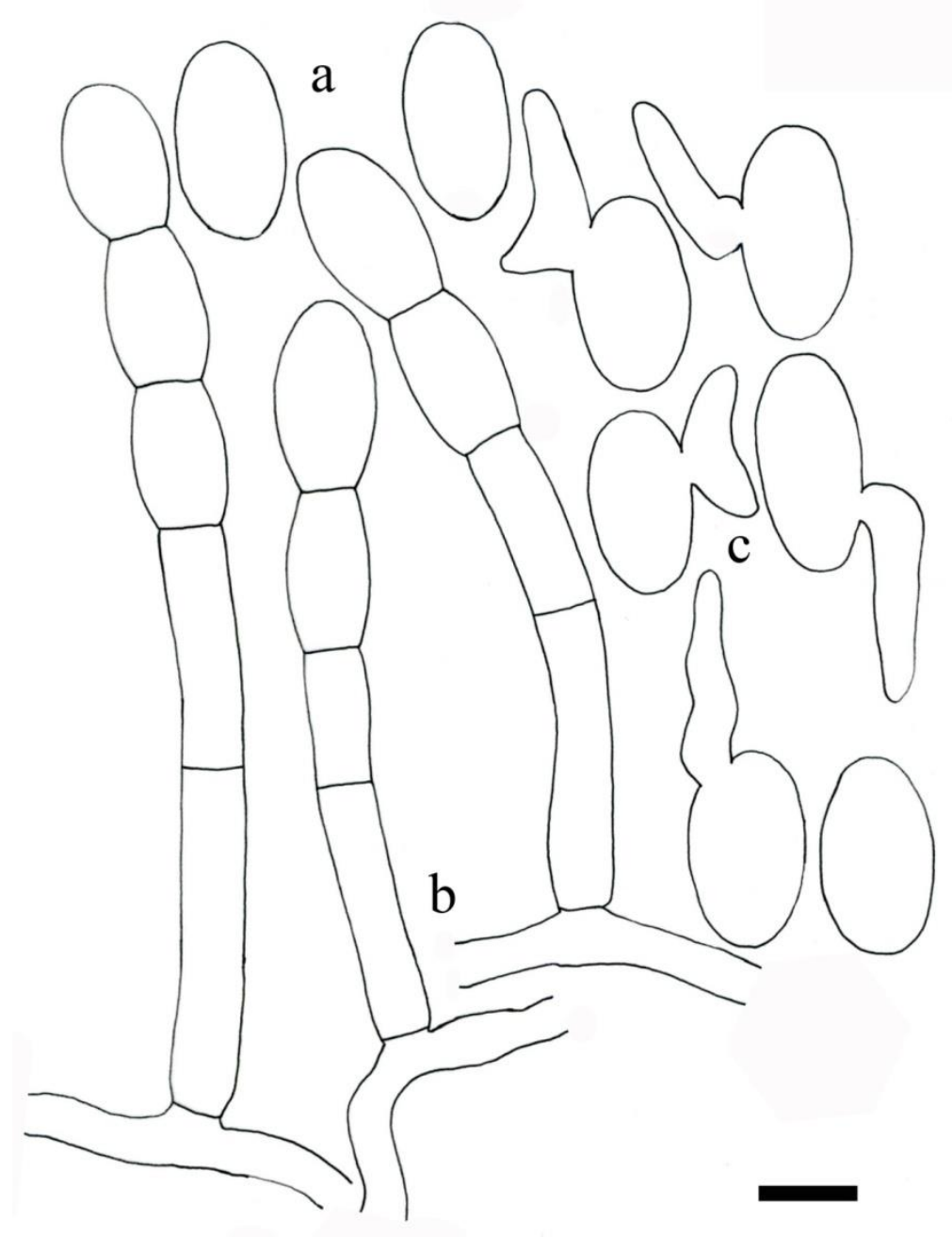

Fig. 20 - Podosphaera sp. on Prunus persica a conidia. b conidiophores. c germ tubes. - Bar $=20$ $\mu \mathrm{m}$.

21. Podosphaera sp. on Prunus mume

Fig. 21

Mycelium amphigenous, effuse or in irregular patches, evanescent to \pm persistent,white or greyish white; hyphae septate, branched, thin-walled, smooth, 5-7 $\mu \mathrm{m}$ wide; hyphal appressoria poorly developed to nipple-shaped; conidiophores straight, arising \pm centrally from the upper surface or somewhat towards one end of the mother cell; foot cells subcylindrical,(45-)50-65(-76) $\times 8-10(-11.5) \mu \mathrm{m}$, followed by $1-3$ shorter cells, forming catenescent conidia; conidia ellipsoidovoid to doliiform-subcylindrical, (23-)27-30(-35) $\times(12-) 14-18(-20) \mu \mathrm{m}$.

Material examined - THAILAND, Chiang Mai Province, Mae Rim, on Prunus mume (Siebold) Siebold \& Zucc. (Rosaceae), 9 January 2016, J. Meeboon, MUMH3717.

Notes - Anamorphic characteristics indicated that the present fungus belongs to the genus Podosphaera. Podosphaera tridactyla (Wallr.) de Bary has been reported as a PM on Prunus s. lat. including Pr. mume (Braun \& Cook et al. 2012). Although the morphological characteristics of this fungus are close to the asexual morph of Po. tridactyla, molecular analyses is necessary to resolve the identity of the fungus. This is the first report of Podosphaera on Pr. mume in Thailand. 


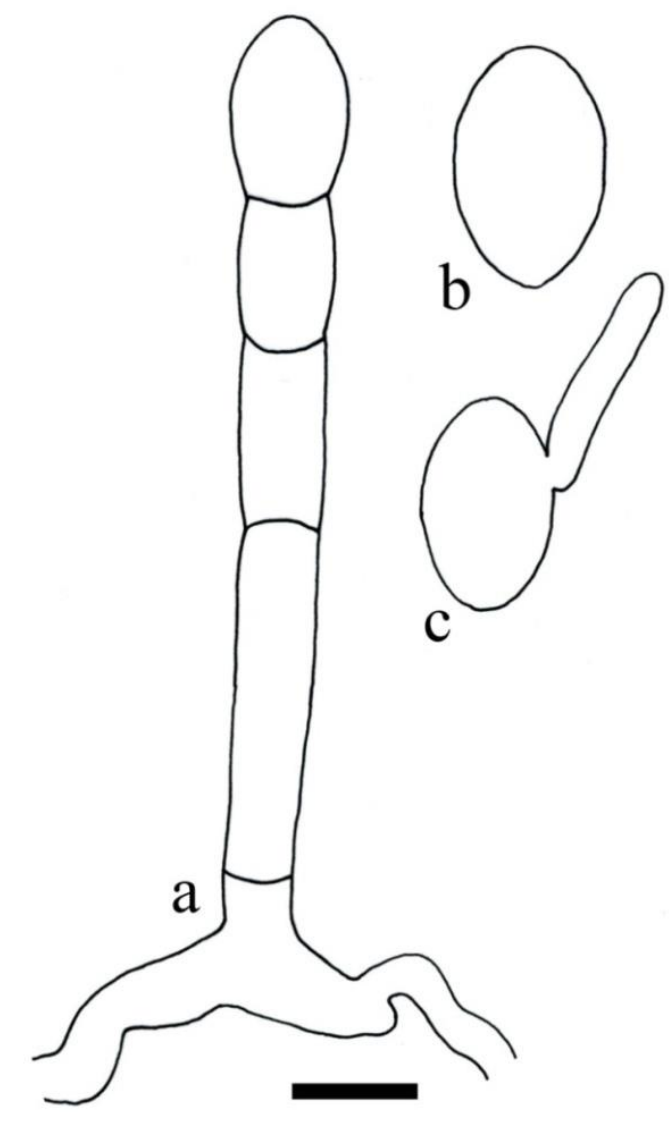

Fig. 21 - Podosphaera sp. on Prunus mume. a conidiophore. b conidium. c germ tube. - Bar $=20$ $\mu \mathrm{m}$.

22. Podosphaera sp. on Viola tricolor

Fig. 22

Mycelium amphigenous, in white irregular patches or effuse, thin to dense, evanescent to persistent; hyphae thin-walled, smooth, 4-6 $\mu \mathrm{m}$ wide; hyphal appressoria indistinct to slightly nipple-shaped, solitary; conidiophores arising from the upper surface of hyphal mother cells, erect or slightly curved; foot cells cylindrical, $60-80 \times 11-12 \mu \mathrm{m}$, sometimes slightly constricted at the basal septum or slightly swollen at the very base, followed by 1-2 shorter cells, forming catenescent conidia; conidia ellipsoid-ovoid to doliiform, 38-41 × 19-21 $\mu \mathrm{m}$; germ tubes \pm lateral, simple to forked, short (brevitubus-subtype of the Podosphaera-type).

Material examined - THAILAND, Chiang Mai Province, Suthep, on Viola tricolor L. (Violaceae), 9 January 2016, J. Meeboon, MUMH3286.

Notes - Podosphaera fuliginea, Po. macularis (Wallr. : Fr.) U. Braun \& S. Takam. and Po. violae (U. Braun) U. Braun \& S. Takam. from North America are species from Podosphaera sect. Sphaerotheca found on Vi. tricolor (Violaceae) worldwide (Braun \& Cook et al. 2012). Furthermore, Braun \& Cook (2012) doubted the report of Podosphaera (S. fuliginea auct.) on Viola spp. in Asia and Europe, and noted these specimens as Po. violae. However, the description of Po. violae anamorph only covers conidia and colony appearance. The current specimen is distinct from asexual morph of Po. violae by having larger conidia (vs $25-35 \times 13-18 \mu \mathrm{m}$ of Po. violae). Since there is limitation in comparing the morphological characteristics, molecular analysis is necessary to determine the relationship of the current specimen with Po. violae. This is the first report of Podosphaera on Vi. tricolor from Thailand. 


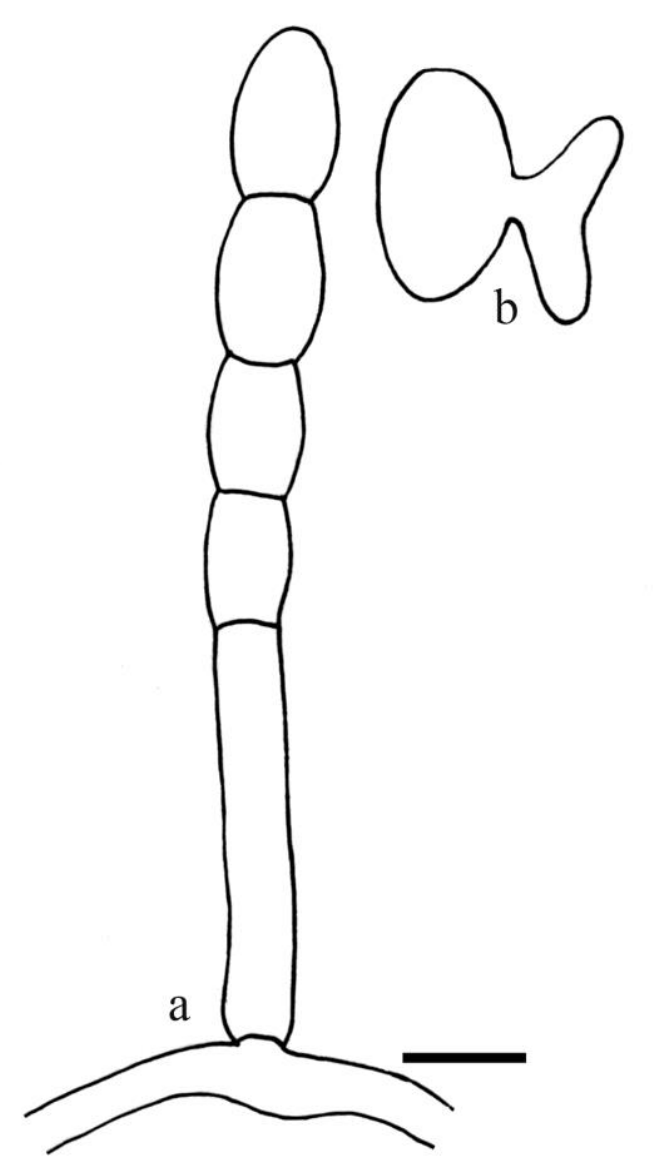

Fig. 22 - Podosphaera sp. on Viola tricolor. a conidiophore. b germ tube. - Bar $=20 \mu \mathrm{m}$. 


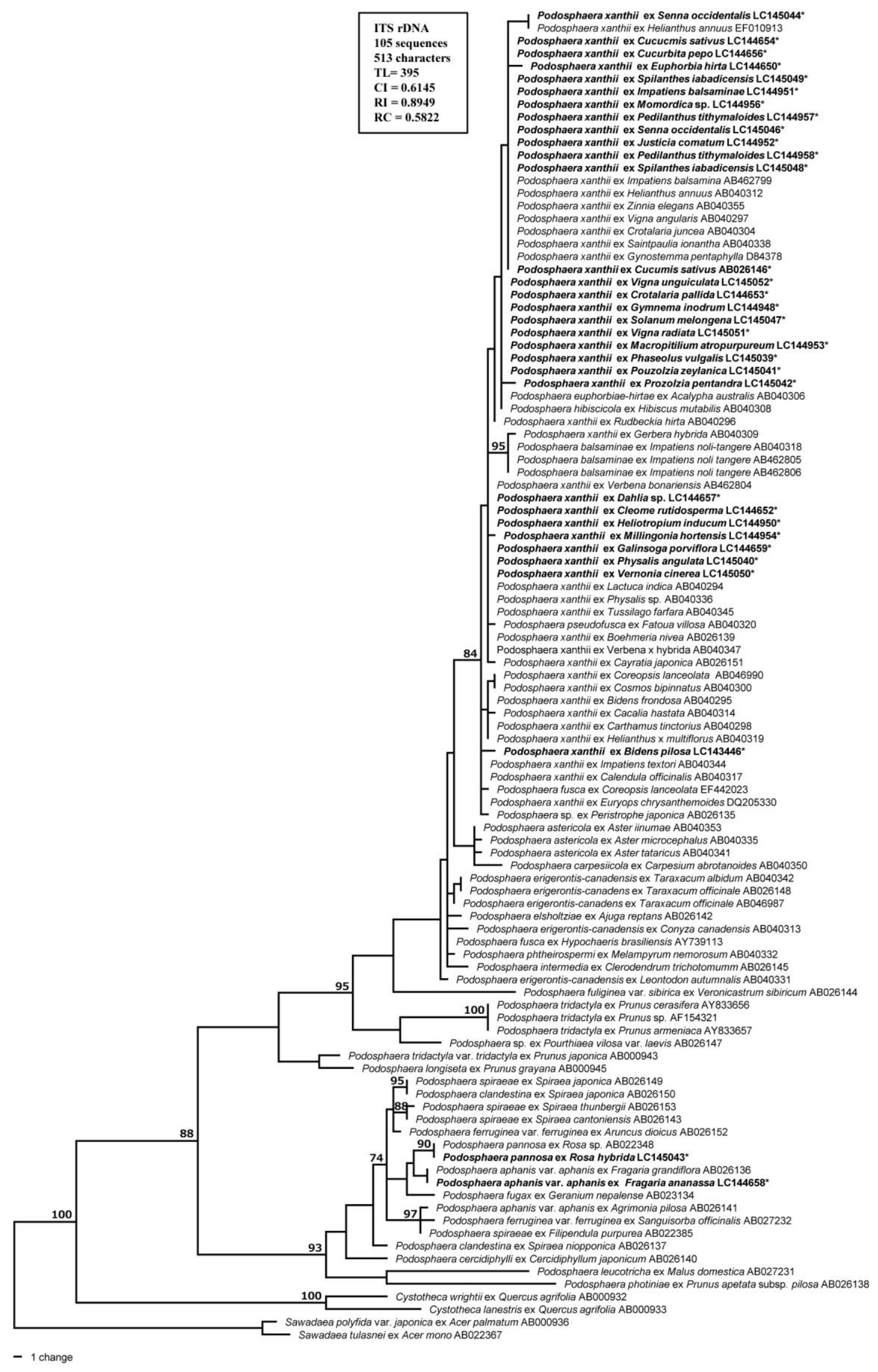

Fig. 23 - One of the most parsimonious trees reconstructed by analysis of ITS sequence data of genus Podosphaera with 79 steps. Bootstrap values of 1,000 replications $>70 \%$ are given on each branch. Sequences determined in this study are shown in boldface and asterisk. The GenBank number for each sequence is presented after species name on the tree. 


\section{Acknowledgements}

This work was financially supported in part by a Grant-in-Aid for Scientific Research (No. 16K07613 and 16F16097) from the Japan Society for the Promotion of Science to ST; and The JSPS postdoctoral fellowship to JM.

\section{References}

Amano (Hirata) K. 1986 - Host Range and Geographical Distribution of the Powdery Mildew Fungi. Japan Scientific Societies Press, Tokyo.

Braun U. 1987 - A monograph of the Erysiphales (powdery mildews). Beihefte zur Nova Hedwigia $89,1-700$.

Braun U, Cook RTA. 2012 - Taxonomic manual of the Erysiphales (powdery mildews). CBS Biodiversity Series No. 11. CBS-KNAW Fungal Biodiversity Centre, Utrecht.

Braun U, Takamatsu S. 2000 - Phylogeny of Erysiphe, Microsphaera, Uncinula (Erysipheae) and Cystotheca, Podosphaera, Sphaerotheca (Cystotheceae) inferred from rDNA ITS sequences - some taxonomic consequences. Schlechtendalia 4, 1-33.

Braun U, Shishkoff N, Takamatsu S. 2001 - Phylogeny of Podosphaera sect. Sphaerotheca subsect. Magnicellulatae (Sphaerotheca fuliginea s.lat.) inferred from rDNA ITS sequencesa taxonomic interpretation. Schlechtendalia 7, 45-52.

Divarangkoon R, Meeboon J, Monkhung S, To-anun C, Takamatsu S. 2011 - Two new species of Erysiphe (Erysiuphales, Ascomycota) from Thailand. Mycosphere 2, 231-238.

Edgar RC. 2004 - MUSCLE: a multiple sequence alignment method with reduced time and space complexity. BioMed Central Bioinformatics 5, 113. http://dx.doi.org/10.1186/1471-2105-5-113.

Farr DF, Rossman AY. 2010 - Fungal Databases, Systematic Mycology and Microbiology Laboratory, Agricultural Research Service, USDA. http://nt.ars-grin.gov/fungaldatabases/ (accessed February 29, 2016)

Felsenstein J. 1985 - Confidence limits on phylogenies: an approach using the bootstrap. Evolution 39, 783-791. http://dx.doi.org/10.2307/2408678.

Giatgong, P. 1980 - Host Index of Plant Diseases in Thailand. Second Edition. Mycology Branch, Plant Pathology and Microbiology Division, Department of Agriculture and Cooperatives, Bangkok, Thailand. pp. 118.

Hirata T, Cunnington JH, Paksiri K, Limkaisang S, Shishkoff N, Grigaliunaite B, Sato Y, Takamatsu S. 2000 - Evolutionary analysis of subsection Magnicellulatae of Podosphaera section Sphaerotheca (Erysiphales) based on the rDNA internal transcribed spacer sequences with special reference to host plants. Canadian Journal of Botany 78, 1521-1530.

Hirata T, Takamatsu S. 1996 - Nucleotide diversity of rDNA internal transcribed spacers extracted from conidia and cleistothecia of several powdery mildew fungi. Mycoscience 37, 283-288. http://dx.doi.org/10.1007/BF02461299.

Ito M, Takamatsu S. 2010 - Molecular phylogeny and evolution of subsection Magnicellulatae (Erysiphaceae: Podosphaera) with special reference to host plants. Mycoscience 51, 34-43.

Junell L. 1967 - Erysiphaceae of Sweden. Symbolae Botanicae Upsaliensis 14, 1-117.

Meeboon J, Divarangkoon R, Takamatsu S. 2013 - Two new species of Erysiphe sect. Uncinula (Erysiphales): Erysiphe fernandoae and E. michikoae. Mycoscience 54, 2-7. http://dx.doi.org/10.1016/j.myc.2012.06.001.

Meeboon J, Takamatsu S. 2013 - Molecular phylogeny reveals the presence of cryptic speciation within Erysiphe japonica (三Typhulochaeta japonica), a powdery mildew on Quercus spp. Mycoscience 54, 69-74. http://dx.doi.org/10.1016/j.myc.2012.07.003.

Park MJ, Park JH, Kwon JH, Shin HD. 2011 - Powdery mildew of Momordica charantia caused by Podosphaera fusca in Korea.The Plant Pathology Journal 271, 99. 
Sawada K. 1933 - Descriptive catalogue of Formosan fungi VI. Bulletin of the Department of Agriculture, Government Research Institute Formosa 61, 1-79.

Shin HD. 1988 - Erysiphaceae of Korea. Thesis, Department of Agricultural Biology, Graduate School of Seoul National University.

Shin HD. 2000 - Erysiphaceae of Korea. Plant Pathogens of Korea 2, 1-320.

Shin HD, La JL. 1989 - Teleomorph of Oidium indigoferae Yen from Korea. Korean Journal of Plant Pathology 5, 257-261.

Shin HD, La YJ. 1992 - Addition to the new records of host plants of powdery mildews in Korea. Korean Journal of Plant Pathology 8, 57-60.

Shin HD, La YJ. 1993 - Morphology of edge lines of chained immature conidia on conidiophores in powdery mildew fungi and their taxonomic significance. Mycotaxon 66, 445-451.

Shin HD, Lee HJ. 1999 - Notes on powdery mildew on Dahlia in Korea. The Korean Journal of Mycology 27, 234-236.

Swofford DL. 2002 - PAUP*: phylogenetic analysis using parsimony (*and other methods), version 4.0b10. Sinauer, Sunderland, MA.

Takamatsu S, Kano Y. 2001 - PCR primers useful for nucleotide sequences of rDNA of the powdery mildew fungi. Mycoscience 42, 135-139.

Takamatsu S, Niinomi S, Harada M, Havrylenko M. 2010 - Molecular phylogenetic analyses reveal a close coevolutionary relationship between Podosphaera (Erysiphales: Erysiphaceae) and its rosaceous hosts. Persoonia 24, 38-48.

Tamura K, Peterson D, Peterson N, Stecher G, Nei M, Kumar S, 2011 - MEGA 5: molecular evolutionary genetics analysis using maximum likelihood, evolutionary distance, and maximum parsimony methods. Molecular Biology and Evolution 28, 2731-2739. http://dx.doi.org/10.1093/molbev/msr121.

Tanda S, Braun U. 1985 - Two new powdery mildew fungi on Carica papaya and Phyllanthus flexuosus. Transactions of the Mycological Society of Japan 26, 315-319.

Thaung, M.M. 2007 - Powdery mildews in Burma with reference to their global host-fungus distributions and taxonomic comparisons. Australasian Plant Pathology 36, 543-551.

To-anun C, Limkaisang S, Fangfuk W, Sato Y, Braun U, Takamatsu S. 2003 - A new species of Brasiliomyces (Erysiphaceae) on Dalbergia cultrata var. cultrata from Thailand. Mycoscience 44, 447-451.

To-anun C, Kom-un S, Sunawan A, Fangfuk W, Sato Y, Takamatsu S. 2005 - A new subgenus, Microidium, of Oidium (Erysiphaceae) on Phyllanthus spp. Mycoscience 46, 1-8.

Walsh SP, Metzger DA, Higuchi R. 1991- Chelex 100 as a medium for simple extraction of DNA for PCR-based typing from forensic material. Biotechniques 10, 506-513.

White TJ, Bruns TD, Lee S, Taylor J. 1990 - Amplification and direct sequencing of fungal ribosomal genes for phylogenetics. In: Innis MA, Gelfand DH, Sninsky JJ, White TJ (eds) PCR protocols: A guide to methods and applications. Acad. Press, San Diego, pp. 315-322.

Yen JM. 1966 - Étude sur les champignons parasites du Sud-Est asiatique V: Notes sur quelques espèces d'Oidium de Malaisie. Revue Mycologie (Paris) 31, 281-310.

Yen JM. 1967 - Étude sur les champignons parasites du Sud-Est asiatique VIII: Quelques espèces d'Oidium de Formose. Cahier du Pacifique 11, 75-116. 